\title{
Islamic Commercial Banking In Europe: A Cross-Country And Inter-Bank Analysis Of Efficiency Performance
}

Ahmad M. Abu-Alkheil, University of Hohenheim, Germany

Hans-Peter Burghof, University of Hohenheim, Germany

Walayet A. Khan, University of Evansville, USA

\begin{abstract}
We examine the relative efficiency performance of the Islamic Bank of Britain (IBB), the first stand-alone full-fledged Islamic commercial bank in the Western world, against conventional banks in the UK, and also against Islamic banks from Muslim-majority countries. We also apply a two-stage Data Envelopment Analysis (DEA) model to determine the impact of internal and external factors on bank's efficiency. In order to investigate the association of the DEA-efficiency scores with the traditional accounting ratios, we estimate the correlation coefficients between the two variables. The efficiency-profitability matrix is used to enable the characterization of the banks' performance profile. Our analysis covers the period from 2005 to 2008.

Our results show that the IBB is technically inefficient. It also has relatively a poor financial performance. The bank's inefficiency stems from both scale (size) and management issues. IBB exhibits, however, an upward trend in efficiency and profitability, particularly in adverse market conditions. Thus, it has a great prospect to increase efficiency and strong potential for further growth in the UK. Additionally, results suggest that the technically more efficient banks are larger, have greater profitability and loans intensity, acquire less debt, and on average have a lower market share. IBB is relatively superior in terms of lending intensity and capital adequacy. Findings further illustrate that the DEA measures can be used separately or concurrently with standard accounting measures in determining Islamic banks performance.
\end{abstract}

Keywords: Islamic Commercial Banking in Europe; Islamic Commercial Banking Efficiency

\section{INTRODUCTION}

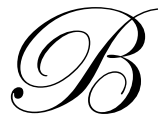

anking is considered as one of the major components of a financial system, since it has a broad impact on the overall financial stability and strength of an economy. It connects economic units and participants in the creation of financial markets. Banking plays a major role of financial intermediation and helps in creation of wealth through the establishment of a series of economic relations. Interest is considered the fundamental source of revenue for banks. As a result, the financial markets and institutions are highly sensitive to changes in interest rates due to their critical role in generating revenues and profits. Any change in the interest rate has an impact on the banking and financial sector. Therefore, the banks are actively engaged in interest rate risk management.

Islamic banking differs from conventional banking in several important ways. The essential feature of Islamic banking is that it is interest-free. Shari 'ah-compliant financial institutions do not deal with interest. ${ }^{1}$ In Islam, interest is considered as a form of exploitation because it is merely a charge on use of money. Consequently, Islamic banking has its own set of unique risks and challenges. This, however, calls for the development of modern mechanisms to allow interest income to be replaced with cash flows from productive sources, such as returns from

\footnotetext{
${ }^{1}$ The prohibition of usury (interest) is not specific to Muslims rather its roots are in Christianity and Judaism.
} 
wealth generating investment activities and operations, which include for example, profits from trading in (real) assets and cash flows from the transfer of usufruct (the right to use an asset). Modern Islamic financing techniques were developed first in Muslim countries of Asia, notably Malaysia. Since the mid-1990s, the boom in the Islamic banking industry and in the widely acceptable and reliable techniques has risen significantly in the Gulf region mainly due to the sudden increase in oil revenues.

Nowadays, Islamic finance is emerging as an alternative to the conventional banks in many parts of the world. Islamic finance is also attracting conventional investors seeking to get evolved into new investment opportunities. For instance, HSBC Amanah, the segregated division of HSBC, provides a range of Shari 'ah compliant financial services such as the Amanah bank account and Amanah home services to meet the needs of the UK Muslim community. Barclays Capital, the investment banking arm of Barclays bank plc, is considered as a market-leading franchise in the Islamic bonds "Sukuk" market. Ahli United Bank (UK) introduced Manzil "the home purchase plans" to help clients purchase residential property in accordance with their religious regulations. Al Buraq - The Arab Banking Corporation (ABC), through its London subsidiary ABC International Bank plc (ABCIB), brings 'alburaq' to offer Shari 'ah-compliant home financing for residential (mortgage) properties in the UK. The Citi Islamic Investment Bank E. C. ("CIIB"), the fully owned subsidiary of Citicorp Banking Corporation, has been continuingly playing a pioneering and innovative role in the industry through Islamic finance windows within Citi. Lloyds TSB have developed a suite of Shari'ah approved products. Last but not least, the Royal Bank of Scotland (RBS)-Islamic banking provides customers with consumer and commercial products based on diminishing Musharaka and Murabaha, etc. ${ }^{2}$

Given the differential behavior of the Islamic banks and the conventional banks, there has always been question about the long run sustainability of Islamic banks which in turn depends heavily on their efficiency performance. The efficiency of conventional banks has been widely studied in the literature to assess the experience of banks in achieving their objectives. Efficiency is defined as a performance measure indicating how prudently a bank is utilizing its resources in producing outputs. It implies improved profitability, better prices and service quality for consumers, and greater amounts of funds intermediated (Berger, Hancock, and Humphrey, 1993). Determining banking efficiency would enable bank's management to identify areas of efficiency and/or inefficiency in comparison to their competitors. Such recognition indeed helps the banks' management to improve its performance and market position. Efficiency estimate captures also the effects of deregulation and financial disruption, institutional failure, problem loans, management quality, market concentration, and the mergers and acquisitions. Thus, the enhanced efficiency in banks contributes to a healthier economy. This is because the banking sector output is highly correlated with economic growth (Berger and Humphrey, 1997).

In practice, to measure banks efficiency, different approaches are applied, either to banks within the financial sector (inter-banking comparison) or to branches within a bank (intra-bank comparison). By and large, Data Envelopment Analysis (DEA) is the widely used efficiency analysis method. The literature on the application of DEA frontier analysis comprises a massive amount of empirical researches, such as Casu and Molyneux (2003).

From an "academic" point of view, despite the considerable development of Islamic banking sector, there are still few studies which explore the efficiency of Islamic banks. Previous studies focused primarily on the conceptual issues of Islamic banking. The main purpose of this paper is primarily to bridge this gap in the literature. Our primary contribution to the literature is our undertaking of the first empirical analysis of the relative efficiency performance of IBB, which is considered as the first stand-alone Islamic commercial bank in the Western world. We basically attempt to answer the following two fundamental questions that arise after reviewing a brief literature on the Islamic banking and efficiency measurement techniques: Does IBB produce superior efficiency compared to the counterparties-conventional banks in the UK? Does IBB tend to outperform Islamic banks in Muslims countries?

\footnotetext{
${ }^{2}$ In diminishing Musharaka (co-ownership), the financier and the client participate either in joint ownership of a property, or in a joint commercial enterprise. The share of the financier is divided into a number of units. The client purchases these units based on a redeeming mechanism until he is the sole owner of the property. On the other hand, Murabaha contract (cost-plus financing) is frequently appears as a form of trade finance based upon letters of credit. This contract involves the sale of an item on a deferred basis. The item is delivered immediately and the price to be paid for the item includes a mutually agreed margin of profit payable to the seller.
} 
To answer the former questions, we provide evidence on the performance of the Islamic Bank of Britain (IBB) over the period 2005-2008. This is based on the overall technical efficiency measurement, Data Envelopment Analysis (DEA), which also examines the bank's pure technical efficiency (PTE) and scale efficiency (SE). In order to specify input-output variables, the output oriented-intermediation approach is selected. Furthermore, the DEA efficiency scores obtained from the first-stage are used as dependent variables in the Ordinary Least Squares (OLS) regression model to investigate the effect of multiple factors on banks' performance. Eventually, to further illustrate the relationship between efficiency and profitability we examine, on one hand, the correlation between the DEA scores and the main accounting measurements, ROA and ROE. On the other hand, we measure the efficiency profitability matrix which has similarity in structure to the product portfolio matrix approach.

This paper is organized as follows. Section 2 provides an overview of the related studies in the literature. Section 3 discusses the methodology and choice of input and output variables for the efficiency model. Section 4 reports the empirical findings. Finally, section 5 presents the overall concluding remarks.

\section{LITERATURE REVIEW}

There is a large body of descriptive literature that offers comparisons of the instruments used in Islamic banking versus conventional banking. It also discusses the legal principles and regulatory challenges related to Islamic banking such as: Jobst (2007), Sundararajan and Errico (2002), and Sole (2007). Existing empirical literature on Islamic banking focuses primarily in assessing the performance of Islamic banks based on financial ratios. For example, Metwally (1997) tests the primary differences among Islamic and conventional banks in terms of liquidity, leverage, credit risk, profitability and efficiency for 30 banks over the period 1992-1994. The statistical evidence suggests that the two groups of banks may be differentiated in terms of liquidity, leverage and credit risk, but not in terms of profitability and efficiency. Similarly, Samad and Hassan (1999) evaluate the inter-temporal and the inter-bank performance of Bank Islam Malaysia Berhad (BIMB) in terms of profitability, liquidity, risk and solvency, and community involvement for the period 1984-1997. They compare BIMB against 8 conventional banks using the financial ratios. The study finds that BIMB is relatively more liquid, less risky but has low average profit compared to conventional banks.

Rosly and Bakar (2003) evaluate the relative financial performance of the Islamic banking scheme (IBS) banks against the mainstream banks in Malaysia for the period 1996-1999. The study argues that the IBS higher recorded (ROA) is not due to efficient investment policy but, rather it is caused by technical default. It concludes that the mainstream banks perform better than Islamic banks due to larger market size and greater experience. Additionally, Samad (2004) examines the comparative performance of six Islamic banks in Bahrain against fifteen interest-based conventional commercial banks with respect to profitability, liquidity risk, and credit risk for a period from 1991-2001. The results indicate that there are no major differences in profitability and liquidity between Islamic banks and conventional banks. In terms of volume (average dollar business), the performance of Islamic banks is far below the conventional banks in Bahrain. Islamic banks, as newcomers to the financial market, are however performing as well as the conventional banks in a similar age group. In addition, Islamic banks are exposed to less credit risk compared to conventional banks. Interestingly, their credit performance is superior to that of conventional banks.

Based on cross-country analysis, Čihák and Hesse (2008) present for the first time a comparative empirical analysis of Islamic banks' with respect to financial stability. The sample covers individual Islamic and conventional banks in 20 banking systems (i.e. Bahrain, Bangladesh, Brunei, Egypt, Gambia, Indonesia, Iran, Jordan, Kuwait, Lebanon, Malaysia, Mauritania, Pakistan, Qatar, Saudi Arabia, Sudan, Tunisia, United Arab Emirates, West Bank and Gaza, and Yemen) over the period 1993 to 2004. They find out that small Islamic banks tend to be financially stronger than small conventional banks. On the other hand, large conventional banks tend to be financially stronger than large Islamic banks. Meanwhile, small Islamic banks tend to be financially stronger than large Islamic banks which may reflect challenges of credit risk management in large Islamic banks.

Despite of the extensive conceptual academic works on Islamic banking and finance, and the use of straightforward financial ratio analysis for understanding and predicting the performance of Islamic banks, there are few studies being attempted to empirically measure the efficiency performance of Islamic banks either in Muslim 's 
countries or in Europe. The lack of coherent evidence regarding the efficiency of Islamic banks is likely to be a consequence of the industry small size and newness.

Among those who investigate empirically the efficiency of Islamic banks is Yudistira (2004). He provides new evidence on the performance of 18 Islamic banks in GCC-States, Indonesia, Malaysia, Algeria, Cambia, Sudan, Egypt and Jordan, over the period 1997-2000. The research work is based on efficiency measurement in which Data Envelopment Analysis (DEA) is utilized to analyze the technical efficiency (TE) and scale efficiency (SE) of Islamic banks. Findings indicate that the inefficiency across Islamic banks is, by and large, small at just over 10\%, which is quite low compared with many conventional counterparts. Islamic banks suffer slight inefficiencies during the global crisis of 1998-9, but performed very well after the difficult periods. Results also suggest that there are diseconomies of scale for small-to-medium Islamic banks which suggests that mergers should be encouraged.

In 2001, Limam uses a stochastic frontier model to examine the technical efficiency of banks in Kuwait from 1994 to 1999. He reports that most banks in his sample are scale efficient therefore, increasing bank size through mergers and acquisition does not substantially enhance technical efficiency of the merged banks. Limam provides evidence to suggest that the larger bank size, higher share of equity capital in assets and greater profitability are associated with better efficiency.

Most recently, Kamaruddin, Safa, and Mohd (2008) apply DEA technique to present new perspectives on performance of Islamic banking operations in Malaysia during the period 1998-2004. They investigate for the first time both cost and profit efficiency of full-fledged Islamic banks and Islamic windows operations of domestics and foreign banks. They find that Islamic banking operators are relatively more efficient at controlling costs than at generating profits. This means, cost efficiency comes from resource management and economies of scale, respectively.

Overall, there is lack of evidence regarding the efficiency performance of Islamic commercial banks operating in the European financial system. This paper intends primarily to put that evidence into practice using the non-parametric deterministic approach, DEA.

\section{METHODOLOGY}

Several approaches have been developed for measuring banks' level of efficiency ${ }^{3}$, ranging from simple financial ratios to complex econometric models. Complex efficiency estimation techniques can be categorized into parametric and non-parametric methods (Berger and Humphrey, 1997). There is no consensus in the literature as to which approach is better as both approaches have advantages and disadvantages. They differ primarily with respect to the assumptions imposed on data. The parametric approaches require assumptions about the particular form of cost or profit function and the distribution of efficiency (Iqbal and Molyneux, 2005). The non-parametric approaches, on the other hand, require no such specification of the functional form. The most commonly used approaches among non-parametric methods are the DEA and the Free Disposable Hull (FDH). While the most widely used parametric methods are the Stochastic Frontier Approach (SFA), the Thick Frontier Approach (TFA) and the Distribution Free Approach (DFA). The next sections (3.1 - 3.4) consider the application of the efficiency measurement of the DEA approach.

\subsection{Technical efficiency measurement using DEA-approach}

DEA is a non-parametric approach that is considered as an alternative method to estimate productive efficiency in the financial sector. ${ }^{4}$ DEA approach shows how a particular bank operates relative to other banks in the

\footnotetext{
3 The modern efficiency measurement begins with Farrell (1957). He proposed that the efficiency of a firm consists of two components: technical efficiency (TE), which reflects the ability of a firm to obtain maximal output from a given set of inputs, and allocative efficiency, which reflects the ability of a firm to use inputs in optimal proportions given their respective prices. The two measures are then combined to provide a measure of total economic efficiency (Coelli, 1996).

4 The concept of production efficiency originated from Cobb and Douglas (1928). The study is premised on the structural relation between inputs and outputs in economic production. Berger and Humphrey (1997) extended the Cobb-Douglas model to the banking sector by focusing mainly on financial sector efficiency.
} 
same sample. It provides a benchmark for best practice technology based on the experience of those banks in the sample. The DEA estimates are based on technological efficiency where efficient firms are those for which no other firm (or linear combination of firms) produces as much or more of output provided given inputs, or uses as little or less input produce a given output. The efficient frontier is composed of these un-dominated firms and the piecewise linear segment that connect the set of input/output combinations of these firms yielding a convex production possibility set (Bauer, Berger, Ferrier, and Humphrey, 1998).

One of the DEA advantages particularly relevant to our study is that it works well with small samples requiring the smallest number of observations. Another advantage of the DEA is that it enables analysts to identify the sources of inefficiency not apparent from financial results. For instance, studies of benchmarking practices utilizing DEA identify numerous sources of inefficiency in some of the most profitable banks. This is because of the high-profit bank may be quite inefficient in processing transactions, which may not be apparent from financial measures (Cooper, Seiford, and Tone, 2007).

DEA method does not impose any assumption on the structural form of banks as it requires no prespecified functional form. Rather, the functional form is generated from the sample of the evaluated firms; hence, it reduces the probability of an incorrect functional model (Berger and Humphrey, 1997). DEA can estimate technical efficiency ${ }^{5}$ under the assumption of Constant-Returns-to-Scale (CRS) and Variable-Returns-to-Scale (VRS). The CRS assumption is only appropriate when all Decision Making Units (DMUs) are operating at optimal scale. Factors like imperfect competition and constraints in finance may cause our sample banks not to operate well at their optimal scale of operations.

On the basis of the prior arguments, this paper compares Islamic banks to counterparties-conventional banks using DEA approach. In order to account for the fact that the sizes of the banks in our sample vary greatly, ranging from large active banks to small banks, we estimate our DEA-model under the assumption of VRS approach as suggested by Banker, Charnes, and Cooper (1984) and Cooper et al. (2007), also known as (BCC-model).

The DEA approach measures efficiency based on either an input-oriented model (i.e. input/output) or an output- oriented model (i.e. output/input). In the former model, the DEA aims to identify technical inefficiency as a proportional reduction in input usage, meanwhile in the later output-oriented model; technical inefficiency is measured as a proportional increase in output production. To date, the literature is uncertain as to the best choice between the two orientation models. The choice of orientation will not have a major impact on efficiency estimations since both approaches will construct the same frontier, and thus the same efficient DMUs (best performers) would be identified. However, inefficient DMUs ranking would possibly change (Coelli, 1996). In this research, we assume an output- oriented approach where the technical inefficiency is measured as a proportional increase in output production. Our preference for this measure is due to its reliability and a better fit to our situation. Islamic banks operating under competitive environment hence, strive to offer the best possible products for their clients. Therefore, they are more likely to solidify their competitive advantage by increasing outputs production rather than reducing the input usage.

\subsection{Data and variables}

Our methodology differs from literature research papers in various aspects. With respect to sample, unlike other studies, we employ 40 banks. The distribution of banks is illustrated in Table 1 below. ${ }^{6}$ Moreover, we examine, for the first time, the relative efficiency of the first and the only fully-fledged Islamic commercial bank in the UK i.e. (the IBB), against counterparties-conventional commercial banks in the UK and also against Islamic banks from Turkey, GCC-States and Malaysia. Furthermore, the study time span 2005-2008 helps to account for the impact of the recent financial crisis on the efficiency of the selected banks.

\footnotetext{
5 The term overall (total), or also called "Technical Efficiency (TE)", is taken from the literature of economics where it is used to distinguish the "technological" aspects of production from other aspects. TE $=[\text { Pure Technical Efficiency (PTE) }]^{*}[$ Scale Efficiency (SE)] (Cooper, Seiford, and Tone, 2006).

${ }^{6}$ Our sample is larger than 30 banks. This makes it appropriate and compatible with previous researches. The advantage of a sample size $\geq 30$ is the applicability of the central limit theorem. The population size of our study is, however, quite similar to other studies employ the DEA technique, such as Darrat, Topuz, and Yousef (2002) and Kamaruddin, Safa, and Mohd (2008).
}

(C) 2012 The Clute Institute http://www.cluteinstitute.com/ 
Table 1

Summary statistics of the study population and the selected sample

\begin{tabular}{|c|c|c|c|c|c|}
\hline Types of banks & Population & Sample* & Country & \multicolumn{2}{|c|}{ Bank Size } \\
\hline & & & & $\underline{\text { Small }}$ & Large \\
\hline I. Islamic bank & 50 & 21 & (GCC)-States, Turkey, Malaysia, and UK** & 12 & 9 \\
\hline II. Conventional bank & 158 & 19 & UK & 6 & 13 \\
\hline
\end{tabular}

* The number of tested banks is significantly reduced due to the exclusion of:

I) the new banks (age $\leq 4$ years),

II) all banks other than the commercial banks,

III) banks whose financial statements were incorporated with their parent banks, and

IV) banks with limited published data ${ }^{7}$

** full list of banks being tested were shown in the appendix.

Empirical studies generally use the banks'total assets as a proxy of their size. We classify Islamic and conventional banks based on average total assets. Banks worth more than $£ 1.5$ bn of assets are categorized as large banks, meanwhile, banks worth less are categorized as small. ${ }^{8} \mathrm{We}$ extract the panel data set from non-consolidated financial statements and employ the computer program (DEAP-version 2.1) which was written by Coelli (1996) to construct DEA-frontiers for the calculation of (TE) and (SE) within the selected period.

In the DEA model, if the number of DMUs is small, then an overestimation of efficiency estimates may result (Alirezaei, Howland and Van de Panne, 1998). This is, however, not an issue in our sample because our sample size is large enough. We manage to include all possible banks and valuable input and output variables in the analysis. The number of inputs and outputs in the DEA model should also be addressed. A DEA model with a higher number of variables will have higher efficiency estimates, thus efficient banks on the frontier will be overestimated. If the number of DMUs $(n)$ is less than the combined number of output and input $(O+I)$; large portion of the DMUs will be identified as efficient. Hence, it is preferred that $(n)$ exceeds $(I+O)$ several times. In this paper, we follow Cooper et al. (2007) and Darrat et al. (2002) who suggest that in order to have an appropriate number of inputs and outputs (to minimize biased estimations) the product of inputs times outputs should optimally be less than the sample size $\left(I^{*} O \leq N\right)$. Based on that, the number of banks (DMUs) in each sample model of our analysis is larger than the product of 3 inputs and 2 outputs.

Moreover, one of the most important assumptions to apply DEA is that the DMUs must be homogenous units; they should be performing the same tasks and should have similar objective. This is actually the case of our sample in which both Islamic and conventional banks have the same individual final objective to earn profit even if there is differences in how to reach this goal.

\footnotetext{
${ }^{7}$ For instance, in Qatar: Alasfa Islamic bank and Masraf al Rayan are new banks. In KSA: Alinma bank is new. In Kuwait: Kuwait international bank is new; Jabeer Islamic bank is under foundation. In Bahrain: Alsalam bank Bahrain is new. In UAE: Emirates Global Islamic bank, Noor Islamic bank, Alhilal bank, and Ajman bank are new; Dubai bank converted to Islamic operations in 2007. In Malaysia: the excluded banks are all new e.g., Affin Islam bank berhat, Alliance Islamic bank Malaysia, Amislamic bank, Hong leong Islamic bank, KFH-Malaysia, and standard chartered saadiaq. In Turkey: Bank Asia is private Finance house; turkiye Finans is new; Cyprus Islamic bank is an offshore bank. Oman has no Islamic banks during our study period (2005-08). According to the FAS as on 30 April, 2009 there are 158 banks incorporated in the UK. This number has been shrunk to 19 which is mainly due to the excluded of the: 1) Private Banks such as SG Hambros Bank. 2) Investment banks such as Dresdner Kleinwort. 3) Merchant banks like Gulf International Bank (UK). 4) Banks with special functions like Wesleyan Bank. 5) Development banks such as Crown Agents Bank. 6) Wholesale banks like CIBC World Markets. 7) New banks such as Europe Arab Bank. 8) All banks whose annual report is consolidated with the parent banks such as: ICICI Bank UK Plc, FBN Bank (UK), Reliance Bank Ltd and Ruffler Bank. 9), Islamic windows, such as Hsbc-Amanah.

8 There is no best description of the key characteristics of small and large banks. According to Federal Deposits Insurance Corporation (2008), the banks that had assets of less than $\$ 1.061$ bn, as of December 31 of either of the prior two calendar years, are considered "small". In this paper, we define the banks which accounts for the top percentile of all banks 'aggregate total assets in each banking industry and constitute $85 \%$ or so of the total, as "large banks" and those below this level as "small banks". We decide to use $£ 1.5$ bn of assets as the best cut point for our sample banks. However, in order to classify banks more accurately, we have also adopted number of other factors. These factors are; the bank's market share (measured by total deposits) and the number of employees in each bank.
} 


\subsection{Selection of input and output variables}

While the multi-product nature of the banking firms is recognized in the literature, there is still no agreement as to the definition and measurement of bank inputs and outputs. The banking literature is divided concerning this issue. Researchers take one of two approaches labeled the intermediation and the production approach. The production approach views banks as producers of loan and deposit services using the traditional factors of production i.e. capital and labor. In the intermediation approach, banks act as financial intermediary to collect deposits and purchased funds, then transform these into loans and other assets. The intermediation approach is preferable to the production approach to model bank behavior. This is because it does not exclude interest expenses, which accounts for a significant level of bank's total costs. In this paper, we follow Yudistira (2004) who uses the DEA intermediation approach arguing that the basic principle of Islamic financial system is the participation in enterprise, employing the funds based on the profit and loss sharing (PLS). This, inevitably implies the importance of Islamic bank's intermediary activities.

Our DEA-model consists of three-inputs and two-output. More specifically, we use "total deposits and short term funding", "total expenses" and "total staff cost or personal expenses" as inputs. Earning assets, "total loans" and "total revenues", represent the model outputs (Table 2). However, total expenses and total revenues are used as inputs and outputs, respectively, because interest plus non-interest expenses (total expenses), and interest plus non-interest income (total revenues) are considered as the key variables that influence wealth maximization. In our analysis, we replace the interest in conventional banks with income distributed to the depositors in Islamic banks to make the comparison between both types of banks accurate. Table 10 (appendix) presents the summary statistics of inputs and outputs.

Table 2

The inputs-outputs used in the DEA models ${ }^{9}$

\begin{tabular}{|c|l|l|}
\hline No. & Inputs & Outputs \\
\hline 1. & $\mathrm{I}_{1}:$ Total Deposits and short term funding & $\mathrm{O}_{1}:$ Total loans \\
\hline 2. & $\mathrm{I}_{2}:$ Total Expenses & $\mathrm{O}_{2}:$ Total Revenues \\
\hline 3. & $\mathrm{I}_{3}:$ Total Staff Cost & \\
\hline
\end{tabular}

The degree of correlation between inputs and outputs has a significant impact on the robustness of the DEA model. Hence, a correlation analysis is imperative to establish appropriate inputs and outputs (Chaparro, Jimenez, and Smith, 1999). The correlation between an input (output) variable with other output (input) variable needs to be strong (high) as the efficiency scores depend on the choice of input and output variables (Lønborg, 2005). If an input (output) variable has low correlation with all the output (input) variables, it may indicate that this variable does not fit the model (Yang, 2009). Results of correlation analysis for each pair of variables are presented in Table 11 in the appendix. As it can be seen, the correlation coefficients between input and output variables and within input variables are high. This means that the bank performance is highly explained by the predictors variables, which is true in the context of Islamic banking, hence, this is a reasonable validation of our DEA models. For instance, the higher comparative performance of Islamic banks deposits requires higher interest expenses, which account for a large portion of total expenses.

\footnotetext{
9 Total deposits include: current, saving and investment deposits from customers, banks and other financial institutions. Total staff costs include: wages, salaries, allowances, bonuses, and other staff related costs. In the context of Islamic banking, on the one hand, total loans (the non interest-bearing loans) include financing to customer's banks and other financial institutions that structured under: Murabaha, Ijarah rental, Mudaraba, Istisna, and Musharaka, etc. On the other hand, total revenues include income from investment of depositor's, shareholder's funds and others in the form of Murabaha, Bei Ajel, Musharaka, income from investment in Sukuk, income from Islamic financing assets and placement, management and arrangement fees, income from international Murabaha, commission, fees and foreign exchange, property related income and return to unrestricted investment accounts, etc.
} 


\subsection{The DEA model}

To illustrate the applications of DEA, assume we have a set of DMUs where each DMU transforms ( $n$ ) inputs to $(m)$ outputs. The efficient DMUs will have the highest ratio of the weighted sum of outputs to the weighted sum of inputs. For each DMU, efficiency $\left(e_{s}\right)$ is calculated as follows (Yudistira, 2004):

$e_{s}=\sum_{i=1}^{m} u_{i} y_{i s} / \sum_{j=1}^{n} v_{j} x_{j s}$, for $i=1, \ldots, m$ and $j=1, \ldots, n$,

For a particular DMU, $y_{i s}$ is the quantity of the $i_{t h}$ output produced whereas $x_{j s}$ is the quantity of the $j_{t h}$ input. $u_{i}$ is the output weight while $v_{j}$ is the input weight. $e_{s}$ is then maximized under the condition that the ratios for all DMUs are " $\leq 1 "$ as follows:

$$
\sum_{i=1}^{m} u_{i} y_{i r} / \sum_{j=1}^{n} v_{j} x_{j r} \leq 1, \text { for } r=1, \ldots, N \text { and } u_{i} \text { and } v_{j} \geq 0 \text {, }
$$

Where Eq.1 ensures that the efficiency ratios are at most one and Eq.2 guarantees that inputs and outputs have positive weights. However, there is a problem with the above formulation due to the unlimited number of solutions it may produce because of its fractional function. Following Charnes, Cooper, and Rhodes (1978), the fractional linear program can be transformed into an ordinary linear program:

$\operatorname{minimize} e_{s}=\sum_{\mathrm{i}=1}^{\mathrm{m}} \mathrm{u}_{\mathrm{i}} \mathrm{y}_{\mathrm{is}}$

subject to $\quad \sum_{i=1}^{m} u_{i} y_{i s}-\sum_{j=1}^{m} v_{j} x_{j r} \leq 0, r=1, \ldots, N$;

$$
\sum_{\mathrm{i}=1}^{\mathrm{m}} \mathrm{v}_{\mathrm{j}} \mathrm{x}_{\mathrm{js}}=1 \text { and } \mathrm{u}_{\mathrm{i}} \text { and } \mathrm{v}_{\mathrm{j}} \geq 0
$$

Furthermore, the above program can be transformed into the dual problem as follows:

$\operatorname{minimize} \xi_{s}$

subject to $\quad \sum_{\mathrm{r}=1}^{\mathrm{N}} \varphi_{\mathrm{r}} \mathrm{y}_{\mathrm{ir}} \geq \mathrm{y}_{\mathrm{is}}, \mathrm{i}=1, \ldots, \mathrm{m}$;

$\xi_{\mathrm{s}} \mathrm{x}_{\mathrm{j} s}-\sum_{\mathrm{r}=1}^{\mathrm{N}} \varphi_{\mathrm{r}} \mathrm{y}_{\mathrm{ir}} \geq 0, \mathrm{j}=1, \ldots, \mathrm{n} ; \varphi_{\mathrm{r}} \geq 0$, and $0 \leq \xi_{\mathrm{s}} \leq 1$.

Where $\left(\xi_{s}\right)$ is the overall technical efficiency (TE) scores of the $s_{t h}$ DMUs. The unity value of 1 indicates the DMU is on the frontier "OC" as shown in Fig. 1. Thus, it is considered to be efficient. The DMU that is located to the right of frontier is considered as inefficient which is shown as point " $S$ " in Fig. 1. The $\left(\xi_{s}\right)$ for " $S$ " is then computed by the ratio of $(\mathrm{AQ} / \mathrm{AS})$. This yields that the DMU must reduce $\left(1-\xi_{s}\right)$ of the input in order to arrive to an efficient DMU at point $Q$. If the linear programming equations (3) and (4) are solved by adding the restriction of $\varphi_{r s}$ $=1$, then there are two further efficiency measurements: the variable return to scale (VRS) which can be shown in 
Fig. 1 as $V V^{\prime}$; and the pure technical efficiency (PTE) which is given by " $\rho s=A R / A S^{\prime \prime} .{ }^{10}$ This means that the SE, which is defined as the extent to which a DMU can take advantage of return to scale by altering its size to achieve the optimal scale, is calculated by $\sigma_{s}=\xi_{s} / \rho s$. The fraction of output lost due to scale inefficiency can be measured as $\left(1-\sigma_{s}\right)$ (Yudistira, 2004).

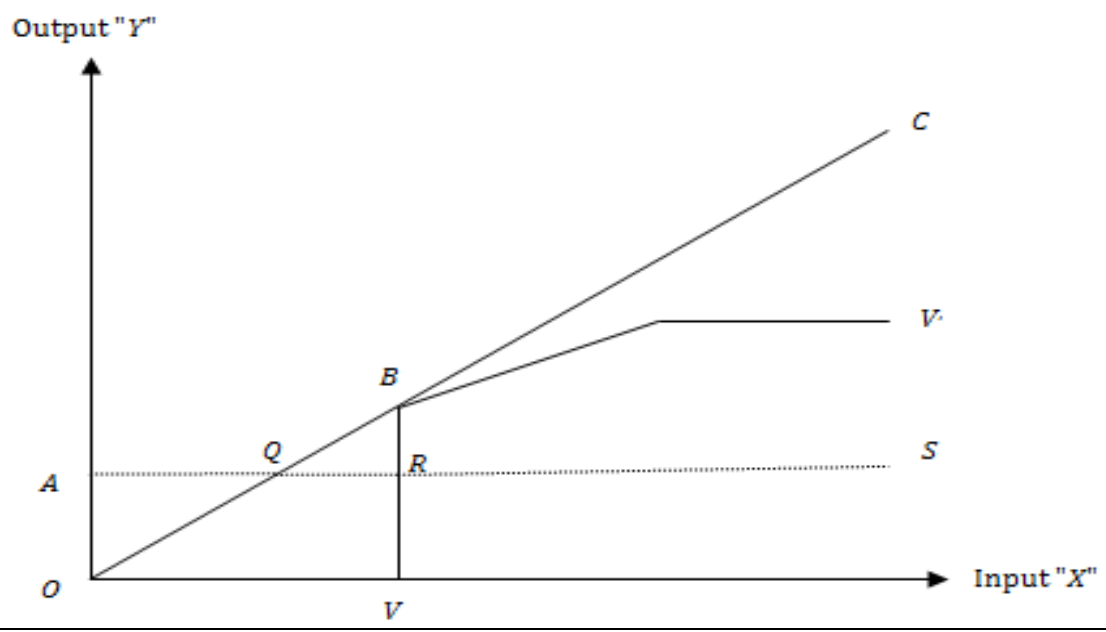

Figure. 1: Efficiency measurements using one output and one input

Source: Yudistira, 2004

SE equals one if and only if the technology exhibits CRS (point "B" in Fig.1). Scale inefficiency may exist due to either increasing (IRS) or decreasing (DRS) return to scale. To obtain these two possible results, the solution of linear programming problems 3 and 4 must be restricted within the sum of the $\varphi_{r}$ from 1 to $N$ is $\leq 1$ in which the pictorial solution can be shown as "OBV" in Fig. 1. The efficiency measure from this technology for the DMU at point $\mathrm{S}$ is $\theta_{s}=A Q / A S$ which also equals $\xi$ s. Thus, DRS can be found when $\sigma s=\theta_{s}$ and IRS when $\sigma s \neq \theta_{s}$. Above all, efficiency appears when $\sigma s=\theta_{s}=\xi_{s}=1$ (Yudistira, 2004).

A DMU is considered efficient if it has a score of $100 \%$ and all slacks are zeros in relation to others. If efficiency score is $100 \%$ (at the optimal solution) and some of the slack variables are non-zeros, then there exists a combination of other units which does not dominate the current output vector of the reference DMU but rather it uses less resources. These DMUs may be termed as weakly efficient (Berger and Humphrey, 1997). In DEA, "slack" can be defined as overuse of input or under production of output that exists even there is a proportional change in the inputs or the outputs. It represents the improvements needed to convert an inefficient unit to an efficient unit. These improvements are in the form of an increase/decrease in inputs or outputs. Slack might be considered as the amount of inefficiency exhibited by non-efficient DMUs and possibly a consequence of poor performance of inputs, outputs or both. If inputs are being used ineffectively, then we have input slack, and conversely we will have output slack.

As indicated by Coelli, (1996), there are three choices regarding the treatment of slacks: $i$ ) One-stage DEA, to calculate slacks residually, ignoring the need for a second optimization step. ii) Two-stage DEA, to move to an efficient frontier by maximizing the sum of slacks required to move from the first-stage projected point to another, and iii) Multi-stage DEA, to conduct a sequence of radial linear programs to identify the efficient projected point. In this proposed paper, we utilize the multi-stage DEA as it is computationally more rigorous and demanding. "The

\footnotetext{
${ }^{10}$ In order to be economically efficient, a bank must first be TE. TE represents the capacity and willingness of an economic unit to produce the maximum attainable output from a given set of inputs and technology. TE is critical to measuring the bank performance, determining the degree of innovative technology adoption and the overall production efficiency. Profit maximization requires a bank to produce the maximum output given the level of inputs employed (i.e. be technically efficient), use the right mix of inputs in light of the relative price of each input (i.e. be input allocative efficient), and produce the right mix of outputs given the set of prices (i.e. be output allocative efficient).
} 
benefits of multi-stage DEA is that it identifies efficient projected points which have input and output mixes that are as similar as possible to those of the inefficient points, and also it is invariant to units of measurement" (Coelli, 1996).

We applied the DEA approach to further examine the input and output "targets" for a bank. These targets are the results of respective slack values added on to original outputs, and subtracted from original inputs. Moreover, target for outputs are calculated by multiplying optimal efficiency scores by the outputs and then adding the slack values to that value. However, it should be noted that some of the efficiency improvement options and the target values may not be applicable and cannot be implemented.

\subsection{Adjustment to the environmental influences: A two-stage DEA-based estimation}

Our sample data considered in this analysis has been adjusted for the differences among sample countries by converting into the UK (£) currency using end of year market rates obtained from respective central banks. All variables in all models have been also deflated by the Consumer Price Index (CPI) of each country in order to account for macro-economic differences across countries during the sample period. Furthermore, to test the statistical association of the efficiency estimates with variables that are not inputs and outputs, and to determine their influence on the bias-corrected efficiency scores, we perform the second- stage of DEA method as suggested by Coelli, Prasada, O'Donnell, and Battese (2005). After solving for DEA in the first-stage, the efficiency scores are then regressed upon the environmental variables which could potentially influence the efficiency of a bank.

In DEA, the dependent variable has an upper limit of $100 \%$, and therefore it is a censored variable. If such censoring was the only concern then Tobit regression could have been used. ${ }^{11}$ But, we have to deal with biases caused by inefficiency; therefore, Tobit regression is not valid (Kumbhakar and Lovell, 2000). McDonald (2009) advocates using (OLS) in the DEA second-stage because it is considered as a consistent estimator. The following (OLS) - regression model is examined in this work: ${ }^{12}$

$$
\begin{aligned}
& \text { E. } 1^{13}:{ }_{\left(e_{\mathrm{s}}\right)}=\alpha+\beta_{1} \mathrm{BP}_{\cdot \mathrm{jt}}+\beta_{2} \text { Per }_{\cdot \mathrm{jt}}+\beta_{3} \mathrm{Liq}_{\mathrm{jt}}+\beta_{4} \log (\mathrm{A})_{\mathrm{jt}} \\
& +\beta_{5} \text { LTA }_{\text {.jt }}+\beta_{6} \text { Depo }_{\cdot j \mathrm{jt}}+\beta_{7} \text { Ind }_{\text {jt }}+\beta_{8} \text { Age }_{\mathrm{jt}} \\
& +\beta_{9} \mathrm{Lev}_{\cdot \mathrm{jt}}+\beta_{10} \mathrm{GDP}_{\mathrm{jt}}+\beta_{11} \mathrm{GeO}_{\cdot \mathrm{jt}}+\varepsilon
\end{aligned}
$$

Where the subscript " $j$ " refers to a bank and the subscript " $t$ " refers to a sample year. The dependent variable " $e_{\mathrm{s}} "$ represents the bank's pure technical efficiency (DEA illustrated in Table 12 (appendix).

\section{EMPIRICAL RESULTS}

This section describes first the DEA results with respect to the efficiency of Islamic banking sector, followed by the results of the second-stage DEA based analysis. It further considers the results from the bank's financial ratio analysis, the correlation analysis of the DEA efficiency scores with financial performance and, eventually, the analysis of the efficiency - profitability matrix.

\footnotetext{
${ }^{11}$ The standard Tobit model assumes that the dependent variable is censored with a limiting value 0 and values ranging between 0 and 1 .

12 Under certain assumptions, OLS gives the best result. It is considred as the Best Linear Unbiazed Estimator "BLUE". OLS is quite sensitive to the presence of outliers and hence we use "Casewise Diagnostics" in SPSS to test for this issue. As a rule of thumb, outliers are points whose standardized residual is greater than 3.3 (corresponding to the .001 alpha level). Based on our analysis, results confirmed the absence of outliers in our sample.

${ }^{13}$ In this paper, the efficiency of Islamic banks is analyzed based on binary comparisons. Two regression models (E1 and E2) were basically measured. The first model (E1: model-M1 and model-M2) measures the relative efficiency of IBB against small and large Islamic banks from Muslim countries (SIBs and LIBs respectively). The second model (E2: model-M3 and model-M4) investigates the relative efficiency performance of the IBB against small and large conventional banks in the UK (SCBs and LCBs), respectively. Empirically, in E2, the dummy " $\beta_{12 \text { Islam.jt }}$ is added and the variable " $\beta_{10} G D P \cdot j$ " is replaced by " $\beta_{10}$ Diver.jt". The endogenous "DEA ${ }_{\mathrm{PTE}}$ " is the pure technical efficiency (PTE) of the $i_{t h}$ bank in period t, while, " $\varepsilon$ ", is the error term. The description of the exogenous variables and the "OLS" main statistical issues are shown in Table 12 and 13 in the appendix.
} 


\subsection{Efficiency of Islamic banking sector}

Table 5 illustrates the DEA-efficiency scores of IBB relative to small Islamic banks from Muslim countries (SIBs) listed in model-M1. The results appear in the table indicates that the IBB has efficiency scores of less than 1 $\left(\mathrm{DEA}_{\mathrm{PTE}}<1\right)$ in each sample year. Hence, it is identified as technically inefficient. The bank 's mean PTE, based on all sample years, is only $35.2 \%$ (calculated as: $(91.9 \%+30.6 \%+38.1 \%+40.1 \%) / 4)$. Thus, it carries out operations, on average, at a significant distance from the efficiency frontier (DEA $\mathrm{EF}_{\mathrm{F}}$, (Chart 1-appendix).

The bank's inefficiency primarily comes from the revenue side, (output slacks (Revenues) $>$ input slacks (Costs)). That is, the bank has non-zero slacks in generating revenues but it has very limited non-zero slacks in the usage of recourses (excess costs) (Table 5.1- model-M1). Consequently, IBB is better in utilizing resources and controlling costs than generating optimal outputs. These results demonstrate that the IBB has definitely substantial room for improvements in the efficiency by reducing costs further and increasing revenues to sustain competitive edge in the European banking industry.

We summarize the findings further by examining the "efficient output-input targets" for IBB. In order to catch up with (lies closer to) the frontier over time in model-M1, IBB is required to increase its output (total revenues) by $£ 8.604, £ 9.272, £ 9.768$ and $£ 12.362$ bn during 2005 through 2008 , respectively. The bank cannot achieve the efficient target levels by augmenting revenues only. The other output (total loans) cannot also be increased because it has zero-slacks. Consequently, IBB should then have reduced its total costs by $£ 1.276$ and $£ 1.271$ bn in 2006 and 2007 respectively, (Table 5.1).

The results seem to imply that the IBB is not only technically inefficient but also inefficient in exploiting the economies of scale given its scale of operations. The inappropriate size (scale) of a bank's operation level $\left(\mathrm{DEA}_{\mathrm{SE}}\right)^{14}$ (too large or too small) can lead to overall (total) inefficiency. In 2005, IBB exhibits an increasing return to scale $\left(\mathrm{DEA}_{\mathrm{IRS}}\right)$, and thus, operates at a scale that is too small. The bank could improve efficiency by scaling up its activities by $3.7 \%$ (calculated as $1-96.3 \%$ ) reaching the score of unity in 2005. In the following three years (2006, 2007, and 2008), the bank has decreasing return to scale (DEA ${ }_{\mathrm{DRS}}$ ) with $\mathrm{DEA}_{\mathrm{SE}} \mathrm{scores}$ of $93.1 \%, 96.8 \%$, and $99 \%$ respectively. This reveals that the bank is operating at scale that is overly large and thus should shrink the output endowments and activities.

By and large, the overall (technical) inefficiency of IBB appears to be mostly due to pure technical inefficiency $\left(\mathrm{DEA}_{\mathrm{PTE}}\right)$. This is due to the low pure technical efficiency in comparison to scale efficiency $\left(\mathrm{DEA}_{\mathrm{PTE}}<\right.$ $\left(\mathrm{DEA}_{\mathrm{SE}}\right)$. For instance, the $\mathrm{DEA}_{\mathrm{SE}, 2005}=96.3 \%>31.9 \%$, and the $\mathrm{DEA}_{\mathrm{SE}, 2006}=93.1 \%>30.6 \%$, etc. Since the $\mathrm{DEA}_{\mathrm{PTE}}$ captures the management practices while the DEA $\mathrm{SE}_{\mathrm{SE}}$ indicates whether the bank operates at optimal economies of scale, the above results suggest that inefficiencies are mostly due to inefficient management practices rather than the size of the bank's operation.

In comparison with small conventional banks ( $\mathrm{SCBs}$ ) in model-M3, the results reveal that IBB fails again to appear on the efficiency frontier over the years 2006, 2007, and 2008. IBB is also inefficient compared to the peer conventional banks except Turkish bank (UK) Limited (Chart 3-appendix). The bank's inefficiency results from the cost (input) side as input slacks is greater than output slacks. The bank could decrease its total expenses and staff cost only by, £ 2.71 and $£ 0.986$ bn in $2005, £ 2.211$ and $£ 1.861$ bn in 2006, £ 1.259 and $£ 1.443$ bn in 2007 respectively, (Table 7.1). Based on the results shown in Table 7, IBB has a high DEA DRS through years 2006-2008 with $\mathrm{DEA}_{\mathrm{SE}}$ equal $91.6 \%, 90.8 \%$, and $92.2 \%$, respectively. These results show that the bank is scale inefficient. Banks pure technical inefficiency again dominates scale inefficiency. This implies that the main source of banks' inefficiency is the managerial inadequacy rather than non- optimal size of operations.

In model-M2 and model-M4 we compare the efficiency of the IBB against large Islamic banks from Muslim-majority countries and also against the counterparties-conventional banks in the UK (LIBs and LCBs)

\footnotetext{
${ }^{14}$ Scale efficiency $(\mathrm{SE})=\mathrm{TE}_{\mathrm{CRS}} / \mathrm{TE}_{\mathrm{VRS}}$. (SE) can be interpreted as follows: (i) If $\mathrm{SE}=1$, then a bank is scale efficient and thus, its combination of inputs and outputs is efficient both under CRS and VRS. (ii) If ( $\mathrm{SE}<1$ ) or (SE > 1), then the combination is not scale efficient.
}

(C) 2012 The Clute Institute http://www.cluteinstitute.com/ 
respectively. IBB is recognized as inefficient in both models. It has efficiency scores of less than one each year. By and large, IBB is inefficient compared to peer banks. The bank however, has relatively better efficiency performance compared with LIBs but it reports worse performance compared with LCBs. Results show that, while the bank has an increasing trend in efficiency scores compared with large Islamic banks, it has unstable efficiency performance in comparison with large conventional banks. Bank's inefficiency primarily results from the revenue side in model-M2 but in model-M4 it comes from the cost side. IBB has low scale efficiency in both model-M2 and model-M4. PTE scores are consistently higher than the scale efficiency scores. This indicates that the bank is scale inefficient (operating at non-optimal level of operations) and it could improve its efficiency by increasing outputs substantially (Tables 6.1 and 8.1).

Considering all results from model-M1 through model-M4, it should be noted that the best efficiency performance of IBB appears first in model-M3 followed directly by model-M2, model-M4, and model-M1 respectively, (Charts 1 through 4-the appendix). In model-M3, the bank is only 8.6\% (calculated as: 1- (average DEA $\left.\left._{\text {PTE }(2005-2008)}\right)=(1+90.1 \%+89.8 \%+85.6 \%) / 4=0.914\right)$ far away from the DEA $A_{E F}$, value of 1 . In model-M2, IBB is $19.3 \%$ away from the frontier $(1-0.807=19.3 \%)$. This amount is much less than the amount the bank requires to become efficient compared with the (LCBs) in model-M4 $(1-0.618=38.2 \%)$ and with the (SCBs) in model-M1 (1$0.352=64.8 \%$ ).

The information on efficiency results from Islamic banks grouped by regional area and bank size provides significant insight into the analysis. It displays that the small Islamic and conventional banks are more efficient than large banks. For instance, (SIBs) from (GCC)-States have relatively a higher average mean efficiency score of 90.2\% (calculated as: $\left.\left(\Sigma(\text { bank }=1)^{N} e_{b i(2005-2008)} / n\right) / N\right)$ : for a particular bank, $e_{b i}$ is the efficiency scores over the sample period, $(n)$ is the number of years, while $(N)$ represents the number of banks), as compared to the (LIBs $=81.3 \%)$ from the same region. Similarly, (SIBs) from the Malaysian banking industry records relatively high average efficiency score of $83.5 \%$ compared to a low mean efficiency scores of $55.4 \%$ attained by (LIBs ). Likewise, (SCBs) from the UK tend to have higher mean efficiency scores of $96.7 \%$ compared to $81 \%$ achieved by (LCBs). This clearly suggests that the "bigger is not necessarily better ". That is to say, the larger the bank, the less efficient it is and the more it can be affected by the financial instability.

The results from the 4-DEA models show that the small Islamic banks in Muslim countries and the IBB in the UK have initially a declining trend in average DEA ${ }_{\text {PTE }}$ over 2005-2007. In spite of the adverse market conditions in 2008, small Islamic banks show a sudden increase in efficiency performance with a higher rate compared with small and large conventional banks and large Islamic banks (Chart 5). IBB has a small asset-size. It is newlyestablished bank. It has also a set of religious financial constraints. This plays an important role in preventing the bank, as well as all other small Islamic banks, from being severely affected by the global economic crisis and consequently, producing a positive efficiency trend.

\subsection{Determinants of bank's efficiency: The (OLS) - regression analysis}

The second-stage DEA based analysis reveals a different set of results. Similar to Darrat et al. (2002) and Miller and Noulas (1996), who report a positive relationship between efficiency and bank's size, our findings also

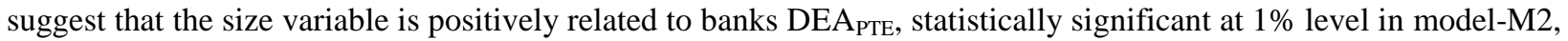
model-M3, and model-M4, (Table 9). Contrary to results from the first stage DEA illustrated in section 4.1 (i.e. the largest scale inefficiencies come from large size banks), the outcomes of DEA in this stage suggest that large banks are relatively more efficient compared to small banks, apparently due to economies of scale effect. A bank indeed sustains a competitive advantage when economies of scale effects are present. ${ }^{15,16}$

\footnotetext{
15 Under ideal conditions, regression and DEA techniques should produce similar results. This is not the case in practice since application of these two techniques on the same data set often produces strikingly different results"(Cubbins and Tzanikadis, 1998).

${ }_{16}$ There are two main theories about the relationship between bank characteristics and efficiency. The shakeout theory proposes that smaller banks may not be able to obtain management ability and enough capital to successfully operate thus, suggesting a positive relationship between size and performance. Alternatively, "the divisibility theory which holds that there will be no such operational advantage accruing to large banks, if the technology is divisible, that is, small-scale banks can produce financial 
Our results also reveal a significant negative relationship between the large banks pure technical efficiency and leverage in model-M2 and model-M4 at 5\% and $0.1 \%$ level respectively. ${ }^{17}$ Such result suggests that the higher performing large banks should acquire less debt. This is because, a higher leverage is related to higher agency costs because of the diverging interests between shareholders and debt holders (Jensen and Meckling, 1976). This moral hazard problem implies a higher risk-taking tendency which could result in greater borrowing costs (Casu and Molyneux, 2003) and low efficiency. Large banks, however, would be subject to systemic risk and possible crises if they were highly leveraged. A small drop in the asset value of a highly leveraged bank leads to distress and possible insolvency particularly in adverse market conditions.

Findings, on the other hand, show that the coefficient of the leverage variable is positive and significant at $10 \%$ level in model-M3. This suggests that the small banks with high levels of leverage should be more efficient. This is because leverage, to a reasonable extent, could allow small-sized bank to make lots of safer loans and therefore plenty of investment returns than larger banks can do. In contrast to results for large banks, leverage could reduce agency costs for small banks and thus have positive effects on efficiency. Leverage may also increase the pressure on banks managers to perform better, because it reduces the moral hazard behavior (Jensen, 1986).

Our regression results also show that the accounting measurements (ROA and ROE) have significant positive effects on banks efficiency almost in all models, (Table 9). ${ }^{18}$ This indicates that more profitable banks are also more efficient. It is common that banks having higher profitability are usually preferred by clients. Therefore, they attract the largest share of deposits and the best potential creditworthy borrowers as well. This creates favorable conditions for the profitable banks to be more efficient.

The findings obtained from DEA-first stage suggest that the overall IBB performs relatively better than some of small and large Islamic banks in Muslim-majority countries, apparently due to its shortened learning curve. Second-stage regression analysis results, in contrast, show that the relationship between the dummy variable region, ( $1=$ if the bank is located in Europe, IBB for example), and a bank's DEA $A_{\mathrm{PTE}}$ is significantly negative in model-M1 and model-M2 at $10 \%$ and $0.1 \%$ level, respectively. This implies that geographical location is a differentiating factor, while assessing the efficiency of banks, which might in part, be due to the unique regulations in the country where the bank operates. Such results demonstrate that small Islamic banks in Europe (IBB in our case) are less efficient than Islamic banks (either small or large) operating in the Middle East (GCC-States), Southeastern Asia (Malaysia) and Eurasia (Turkey). This indicates, however, that the Islamic banks outside Muslim-majority countries experienced more difficulties, particularly during the global economic crisis, to reach the optimal levels of efficiency which could be due to strict conventional regulations.

The proxy of market share (the total deposits) reveals a statistically significant negative relationship with the DEA $\mathrm{ATE}_{\mathrm{PT}}$ in model-M2, model-M3, and model-M4 at 1\%,0.1\% and 5\% levels, respectively. This suggests lower market share is associated with the banks which enjoy a higher degree of efficiency thus diminishing the market leadership argument. Such a result implies that banks with small market share can be equally efficient or even more compared to market dominant banks. It appears that maintaining or expanding markets share might involve additional costs and resources that might reduce efficiency.

Based on our analysis, results indicate that the dummy variable (ISLAM) is negatively statistically significant predictor of banks' performance at $1 \%$ level in Model-M3 (IBB is the only Islamic bank in this model). The coefficient of this predictor shows a significant smaller DEA ${ }_{\text {PTE }}$ scores for IBB compared to other banks. Such a result offer evidence that the small conventional banks in the UK perform considerably different and relatively better than IBB in terms of efficiency performance.

services at costs per unit output comparable to those of large banks, suggesting no or possibly negative association between size and performance" (Sufian, 2007).

17 Size variable is significant in model-M3 (but not model-M1). Although SCBs, IBB, and SIBS have assets of less than $£ 1.5$ bn, an examination of banks financial statements reveal that SCBs and SIBs are still larger than IBB. So, apparently they enjoy relative scale economies over IBB.

18 Due to the high correlation between ROA and ROE (model-M1, $r=0.795$. model-M2, $r=0.933$, model-M3, $r=0.913$, model$\mathrm{M} 4, r=0.821$ ), the later measure was dropped from the analysis.

(C) 2012 The Clute Institute http://www.cluteinstitute.com/ 
Previously we observed that the dependency factor has an insignificant relationship with DEA $A_{\text {PTE }}$ in the context of Islamic banking. Nevertheless, results from the conventional banking industry, in model-M3 and modelM4, show a significant inverse relationship between the two variables at $10 \%$ and 5\% level, respectively. These findings illustrate that subsidiaries, or conventional banks acting as a part of a banking group, have lower efficiency scores compared to the stand alone banks. ${ }^{19}$

To control the bank-specific lending intensity, we use total loans divided by total assets as a proxy. Bank loans are expected to be the main source of revenue thus, are expected to impact efficiency positively. In our paper, the proxy of bank's loan intensity reveals an insignificant positive relationship with all DEA ${ }_{\text {PTE }}$ in both, model-M1 and model-M3. Those findings imply that banks with higher loans intensity might have either higher or lower efficiency. In contrast, we find a significant positive coefficient in model-M2 and model-M4 at $10 \%$ level. ${ }^{20}$ The results indicate that, loans of a bank seem to be more highly valued than alternative bank outputs, i.e. investments and /or securities. This might support the idea that the banks market capability to offer more competitive loan portfolios might be a resulted from their efficient operations. This is due to their ability to perform more productively with lower costs (Sufian and Zulkhibri, 2007).

To capture the possible effects of the liquidity and the absence of the international inter-bank money markets for Islamic banks on their efficiency, the liquid assets to total deposits and short term funding ratio is used as a proxy. We expect that banks with a higher amount of net liquid assets will be less efficient. Banks seek to balance the benefits of high levels of liquidity with the costs of high liquidity. Such balancing may adversely affect the investment returns. Our empirical analysis reveals an insignificant relationship between banks liquidity and their performance in model-M1, model-M3, and model-M4. Surprisingly, the predictor variable (liquidity) in model-M2 reveals a negative significant relationship with $\mathrm{DEA}_{\mathrm{PTE}}$ at $1 \%$ level. This indicates that large Islamic banks that accumulate a significant amount of liquid resources might operate under worst efficiency conditions. This also suggests that the excess liquidity, due to the Islamic law restrictions, has to be invested to achieve efficiency gains. It is worth noting that, too little liquidity might force the bank to borrow at penal rates from the interbank market and/or central bank. However, this is not viable for Islamic banks due to the absence of international inter-bank money market.

With respect to the relationship between the bank's age and its DEA association between the two variables in all models. Theoretically speaking, this could be due to the fact that older banks are not flexible to make the rapid adjustments to changing circumstances as opposed to new banks that have a short learning curve, and are considered more innovative and entrepreneurial (Kapelko, Prior-Jimènez, RialpCriado, 2008). However, one stream of research suggests that new banks suffer from liability of newness. Not only because of the risk of their loans, but also because depositors and established banks will demand premium if they are to invest in these young banks (Gorton and Winton, 1998).

Our results demonstrate an insignificant relationship between the product diversity and banks $\mathrm{DEA}_{\mathrm{PTE}}{ }^{21}$

\footnotetext{
19 By testing both model-M1 and model-M2 together (i.e. regardless of the size differences) the dependency measure reveals a significant positive relationship with the efficiency scores at $5 \%$ level. Such result indicates that the Islamic subsidiaries perform better than stand-alone banks. This might be due to the small size of subsidiaries since the Islamic product schemes become more complex as the size of Islamic banks increase which negatively affect the bank's efficiency.

$20 \mathrm{"} \alpha$ " is the significance level that the researchers decide to accept. The choice of it is somewhat arbitrary, although in practice values of $0.1,0.05$, and 0.01 are common and generally considered "acceptable". However, at a given level of alpha, the smaller the $P$-value, the higher the probability of rejecting the null hypothesis.

21 We find a negative insignificant relationship between the predictor "diversification" and the DEA diversification predictor has been dropped from model-M3 to allow for better results and to meet the regression main assumptions. This leaves the question of whether Islamic banking diversification lead to efficiency or not. However, the universal set of investment to Islamic banks is limited due to Shari'ah restrictions, thus they enjoy a lower diversification benefit than their conventional counterparts. Furthermore, Islamic banks have facing regulations that create incentives to diversify their portfolios. For example, each source of financing that a bank earn raise implies a different degree and type of market discipline. Equityholders care about returns to their equity and might prefer riskier portfolio than would debt-holder, etc. Hence, diversification per service has no guarantee for better efficiency. To verify the proposition of less diversified Islamic banks, we test the differences in the structure of the bank's income. Following Laeven and Levine (2007), we calculate the measure of income diversity as
} 
The results fail to produce a conclusive and casual correlation between increased investment in skills and increased efficiency. Efficiency of human resource management has shown a statistically insignificant relationship with DEA $_{\text {PTE. }}{ }^{22}$ In theory, personal expenses are estimated to impact performance negatively because efficient banks are expected to operate at lower cost. Despite of that, the usage of new electronic technology has made the wage expenses to fall, therefore, the lower cost ratio may impact performance positively.

Eventually, results failed to find any evidence of an association between the growth rate of GDP and the banks DEA $\mathrm{PTE}_{\mathrm{PT}}$. Our results do not support the idea that the favorable economic conditions seem to stimulate higher efficiency due to supposedly positive effect on the demand and supply for banking services.

\subsection{An overview on the bank's Financial Ratios Based Analysis - (FRA)}

We extend the study further by examining the determinants (the exogenous variables) of a bank's efficiency. Results reveal that, the small Islamic banks from Muslim-majority countries and IBB from the UK demonstrate stronger capital adequacy ratios compared to large conventional banks. Small conventional banks are better run compared to all other banks in the sample (Table 14-appendix). It is significantly more complex for Islamic banks to adjust their credit risk monitoring system as they become bigger. Large Islamic banks tend to engage more in profit and loss sharing (PLS) arrangements compared to small ones thus, monitoring (PLS) schemes becomes more diverse and difficult to standardize which results in adverse selection and moral hazard (Čihák, and Hesse, 2008). However, large Islamic banks from Muslim countries are financially outperforming small Islamic banks from (GCC)-States and Malaysia. This could be partially due to the better diversification and/or economies of scale.

Financial results further illustrate that there is a slight difference in profitability, liquidity and leverage between the IBB and other banks in the sample. IBB is relatively superior in terms of lending intensity and capital adequacy, which enables the bank to offer more reasonable terms on loans, attain higher profitability, and ultimately gain a larger market shares over the inefficient banks. Empirical evidence from (ROE) tends to show that IBB has certainly an increasing trend in profitability in contrast to some of its conventional peers in same size, thanks to profit and loss sharing, making its profitability less volatile. "The main reason for such a difference is that Islamic banks benefit from a market imperfection, i.e. the availability of large amounts of non-remunerated deposits in their books, which considerably decrease the cost of funding" (Hassoune, 2001).

\subsection{Correlation of DEA efficiency scores with financial performance}

To examine the relationship between efficiency and profitability, we estimate the correlation coefficient between the two variables. We are interested in investigating whether the DEA results are consistent with the traditional accounting measures commonly used for comparing performance of Islamic banks. We first use ROA and ROE as measures of bank's profits. We then calculate the "Spearman's rho" correlations, between the estimated DEA efficiency scores and the bank's profitability ratios, because it is an efficient estimator regardless of the distributions of variables. It also minimizes the effect of outliers on correlation coefficients. The null hypothesis states that the correlation coefficient between variables is zero.

\footnotetext{
"income diversity=1-(net interest income-other operating income / total operating income)". This variable captures the degree to which banks diversify from traditional lending activities to other activities. For Islamic banks, the net interest income is generally defined as the sum of the positive and negative income flows associated with the PLS arrangements. Consequently, the result of our simple calculations of diversification implies that conventional banks in general are much diversified than Islamic banks. For example but not limited, the average value of diversity measure during the period 2005-2006 for IBB is $10 \%$ whereas it is much higher for Bank of Beirut (UK) with about $43 \%$.

${ }_{22}$ The predictor "personal expenses" shows an insignificant relationship with efficiency in all models. Strikingly, when we measure the effect of skills utilization on efficiency for all Islamic banks (small \& large) which are operating in Muslim countries, analysis reveals a significant positive relationship with the efficiency scores $(\mathrm{t}=2.868, p<0.01)$. This indicates that there is a casual correlation between increased investment in labor and banks efficiency.
} 
It is clear from Table 3 below that the correlation coefficients of accounting measures are statistically and significantly different from zero in model-M1 and model-M2 (IBB, and small and large Islamic banks from Muslimmajority countries, respectively). This suggests that the efficiency measures are strongly associated with traditional accounting measures of performance in relation to the Islamic banking industry, and thus can easily be used by Islamic banks as a substitute of conventional accounting measures of performance. Such findings support Isik and Hassan, (2002) and Miller and Noulas (1996) who find that the most profitable banks are also the most efficient.

Table 3

The correlation coefficients between DEA PTE scores and accounting measures

\begin{tabular}{|c|c|c|c|}
\hline Correlation matrix & The model & ROA & ROE \\
\hline \multirow{3}{*}{ DEA $_{\text {PTE (VRS) }}$} & M1 & $0.366^{*}$ & $0.346^{*}$ \\
\cline { 2 - 4 } & M2 & $0.609^{* *}$ & $0.546^{* *}$ \\
\cline { 2 - 4 } & M3 & 0.154 & 0.215 \\
\cline { 2 - 4 } & M4 & $0.317^{*}$ & 0.050 \\
\hline
\end{tabular}

*: Correlation is significant at the 0.05 level (2-tailed),

**: Correlation is significant at the 0.01 level (2-tailed).

In contrast, the accounting measures are found to be relatively statistically insignificant in model-M3 and model-M4 (small and large conventional banks in the UK, respectively). This indicates that the information contained in the standard accounting measures are not closely corresponded to that contained in efficiency measures in the UK conventional banking system. The main argument is that environmental factors could affect the attainment of profitability.

\subsection{The efficiency - profitability matrix}

In this analysis, we primarily focus on evaluating the performance of small Islamic and conventional banks based on an efficiency-profitability matrix (Table 4). The median value is used to split the matrix into two halves to create high and low groups of profitability, as measured by ROA, and efficiency scores as measured by DEA. We further split the matrix into four quadrants: stars, question marks, sleepers, and dogs.

Table 4

The efficiency - profitability matrix

\begin{tabular}{|c|c|c|c|}
\hline \multicolumn{4}{|c|}{ Profitability (ROA): } \\
\hline High & Sleeper & $M 1:\left(N^{*}=3\right.$ or $\left.25 \%\right) . M 3:(\mathrm{N}=3$ or $43 \%)$ & Star $M 1:(\mathrm{N}=3$ or $25 \%) . \quad M 3:(\mathrm{N}=2$ or $29 \%)$ \\
\hline Low & Question Mark & $\mathrm{M} 1:(\mathrm{N}=4$ or $33 \%) * * . \mathrm{M} 3:(\mathrm{N}=1$ or $14 \%) * * *$ & Dogs $M 1:(\mathrm{N}=2$ or $17 \%) . \quad \mathrm{M} 3:(\mathrm{N}=1$ or $14 \%)$ \\
\hline DEA PTE & Low & & High \\
\hline
\end{tabular}

The star quadrant consists of DMUs which exhibit a high level of profitability and efficiency and thus, considered as the flagship banks. The banks falling in sleeper category have high profitability but low efficiency which is not a good sign from long-term perspective. These sleeper banks are profitable due to primarily more favorable environmental conditions than good management. The question marks category has low profitability and low efficiency. They have a potential for greater efficiency and possibly greater profits. The dogs have a low profitability but high efficiency hence, they are efficient, but are still not profitable. They are efficiently operated units but low on profitability due to an unfavorable environment.

Our analysis suggests that the IBB falls in the question marks quadrant. This indicates that the bank has a low profitability and efficiency. Consequently, IBB is considered as under-performing but has the potential to increase its operating efficiency. By and large, IBB is probably under-resourced and lacks appropriate skills. Thus, 
with a favorable environment and additional resources, it can be expected to enhance its efficiency and profitability performance. By increasing efficiency, the bank can possibly move to the "star" quadrant.

\section{CONCLUSIONS}

Results based on the extensive analysis in this paper show that the IBB is technically inefficient. It has, on average, a poor and under-performing financial performance. IBB is also inefficient in exploiting the economies of scale given its scale of operations. It appears that the IBB inefficiency is driven, to a large extent, by inadequate management compared with small Islamic banks in Muslim-majority countries and small conventional banks from the UK. In comparison with large banks, either Islamic or conventional, the IBB relative inefficiency becomes largely due to the non-optimal size.

IBB, however, exhibits, in comparison to other Islamic banks, an increasing trend in efficiency performance over sample years due to small size and newness. IBB, as well as all small Islamic banks, tend also to have better financial performance than large Islamic banks mainly due to credit risk monitoring arrangements. Large conventional banks, on average, have an upward trend of estimated efficiency, generally with declining increments. Despite the prevailing market conditions being adverse, small Islamic banks (including IBB) and small conventional banks exhibit initially, compared to the large Islamic and conventional banks, poor efficiency scores which subsequently gradually increase with the passage of time. These results show that, with a favorable environment and additional resources, IBB has a substantial room for improvements to sustain its competitive edge in the banking industry by reducing costs and increasing revenues. However, IBB is, on average, better in utilizing its resources and controlling costs than generating optimal levels of revenues.

Overall, results suggest that the optimal size for the IBB to achieve better levels of efficiency performance is neither large nor small rather medium. The idea of medium-size banking has bloomed at the time of the current global crisis. Since then many small banks are becoming acquisition candidates while large banks are more affected by the financial instability and thus recognized as a troublesome due to the high leverage and complex risk exposures.

Empirical findings further illustrate that the DEA-efficiency measures are highly correlated with ROA and ROE, and thus can be used separately or concurrently with the standard accounting measures of performance in determining the performance of Islamic banks in the UK (IBB) and in Muslim-majority countries. Although not widely used, DEA can be adopted along with financial ratios to make comparisons of performance more robust. However, there is an absence of such argument in the UK conventional banking system at which the information contained in the conventional financial measures are not closely corresponded to that contained in efficiency measures.

Eventually, overall results suggest that the banks with higher efficiency levels are larger in size (total assets), tend to exhibit higher profitability and loans intensity, acquire less levels of debt, and have relatively a smaller market share. IBB, however, is relatively superior in terms of lending intensity and capital adequacy. 
Table 5 Summary of the bank's DEA-efficiency scores in model-M1*

\begin{tabular}{|c|c|c|c|c|c|c|}
\hline Year & The country & The bank** & crste & vrste & scale & rts \\
\hline 2005 & UK & IBB & 0.307 & 0.319 & $0 \quad 963$ & irs \\
\hline 2005 & Qatar & Qatar International Islamic Bank & 0.813 & 1.000 & 0.813 & $\mathrm{drs}$ \\
\hline 2005 & Bahrain & Khaleeji Commercial Bank & 1.000 & 1.000 & 1.000 & - \\
\hline 2005 & Bahrain & Bahrain Islamic Bank & 1.000 & 1.000 & 1.000 & - \\
\hline 2005 & Bahrain & Shamil Bank & 0.453 & 0.497 & 0.912 & $\mathrm{drs}$ \\
\hline 2005 & Bahrain & Abc Islamic Bank & 1.000 & 1.000 & 1.000 & - \\
\hline 2005 & U.A.E & Sharjah Islamic Bank & 0.975 & 1.000 & 0.975 & $\mathrm{drs}$ \\
\hline 2005 & Kwuait & Boubyan Bank & 0.893 & 0.898 & 0.994 & $\mathrm{drs}$ \\
\hline 2005 & Malaysia & RHB & 0.790 & 0.793 & 0.995 & irs \\
\hline 2005 & Malaysia & CIMB & 0.055 & 1.000 & 0.055 & irs \\
\hline 2005 & Turkey*** & Albaraka Turk & 0.621 & 0.761 & 0.816 & $\mathrm{drs}$ \\
\hline 2005 & Turkey & Kuveyt Turk & 0.626 & 0.893 & 0.702 & $\mathrm{drs}$ \\
\hline 2006 & UK & IBB & 0.285 & 0.306 & 0.931 & $\mathrm{drs}$ \\
\hline 2006 & Qatar & Qatar International Islamic Bank & 1.000 & 1.000 & 1.000 & - \\
\hline 2006 & Bahrain & Khaleeji Commercial Bank & 0.985 & 1.000 & 0.985 & irs \\
\hline 2006 & Bahrain & Bahrain Islamic Bank & 0.596 & 0.614 & 0.970 & irs \\
\hline 2006 & Bahrain & Shamil Bank & 0.591 & 0.625 & 0.946 & $\mathrm{drs}$ \\
\hline 2006 & Bahrain & Abc Islamic Bank & 1.000 & 1.000 & 1.000 & - \\
\hline 2006 & U.A.E & Sharjah Islamic Bank & 0.837 & 0.926 & 0.904 & drs \\
\hline 2006 & Kwuait & Boubyan Bank & 0.806 & 0.841 & 0.959 & $\mathrm{drs}$ \\
\hline 2006 & Malaysia & RHB & 0.991 & 1.000 & 0.991 & $\mathrm{drs}$ \\
\hline 2006 & Malaysia & CIMB & 0.629 & 0.824 & 0.764 & irs \\
\hline 2006 & Turkey & Albaraka Turk & 0.657 & 0.820 & 0.801 & $\mathrm{drs}$ \\
\hline 2006 & Turkey & Kuveyt Turk & 0.691 & 0.986 & 0.701 & $\mathrm{drs}$ \\
\hline 2007 & UK & IBB & 0.369 & 0.381 & 0.968 & $\mathrm{drs}$ \\
\hline 2007 & Qatar & Qatar International Islamic Bank & 1.000 & 1.000 & 1.000 & - \\
\hline 2007 & Bahrain & Khaleeji Commercial Bank & 1.000 & 1.000 & 1.000 & - \\
\hline 2007 & Bahrain & Bahrain Islamic Bank & 0.635 & 0.671 & 0.947 & $\mathrm{drs}$ \\
\hline 2007 & Bahrain & Shamil Bank & 0.658 & 0.706 & 0.932 & $\mathrm{drs}$ \\
\hline 2007 & Bahrain & Abc Islamic Bank & 1.000 & 1.000 & 1.000 & - \\
\hline 2007 & U.A.E & Sharjah Islamic Bank & 0.761 & 0.879 & 0.866 & $\mathrm{drs}$ \\
\hline 2007 & Kwuait & Boubyan Bank & 0.721 & 0.858 & 0.840 & drs \\
\hline 2007 & Malaysia & RHB & 0.612 & 0.845 & 0.724 & $\mathrm{drs}$ \\
\hline 2007 & Malaysia & CIMB & 0.246 & 0.355 & 0.692 & $\mathrm{drs}$ \\
\hline 2007 & Turkey & Albaraka Turk & 0.646 & 0.934 & 0.691 & $\mathrm{drs}$ \\
\hline 2007 & Turkey & Kuveyt Turk & 0.629 & 0.948 & 0.663 & $\mathrm{drs}$ \\
\hline 2008 & UK & IBB & 0.397 & 0.401 & 0.990 & $\mathrm{drs}$ \\
\hline 2008 & Qatar & Qatar International Islamic Bank & 0.871 & 1.000 & 0.871 & $\mathrm{drs}$ \\
\hline 2008 & Bahrain & Khaleeji Commercial Bank & 0.852 & 1.000 & 0.852 & $\mathrm{drs}$ \\
\hline 2008 & Bahrain & Bahrain Islamic Bank & 0.522 & 0.758 & 0.689 & $\mathrm{drs}$ \\
\hline 2008 & Bahrain & Shamil Bank & 0.811 & 1.000 & 0.811 & $\mathrm{drs}$ \\
\hline 2008 & Bahrain & Abc Islamic Bank & 1.000 & 1.000 & 1.000 & - \\
\hline 2008 & U.A.E & Sharjah Islamic Bank & 0.820 & 1.000 & 0.820 & $\mathrm{drs}$ \\
\hline 2008 & Kwuait & Boubyan Bank & 0.671 & 0.981 & 0.684 & $\mathrm{drs}$ \\
\hline 2008 & Malaysia & RHB & 0.585 & 0.863 & 0.678 & $\mathrm{drs}$ \\
\hline 2008 & Malaysia & CIMB & 0.549 & 1.000 & 0.549 & $\mathrm{drs}$ \\
\hline 2008 & Turkey & Albaraka Turk & 0.675 & 1.000 & 0.675 & $\mathrm{drs}$ \\
\hline 2008 & Turkey & Kuveyt Turk & 0.626 & 1.000 & 0.626 & $\mathrm{drs}$ \\
\hline
\end{tabular}

Table 5.1: Summary of DEA- slacks and targets (IBB: model-M1).

\begin{tabular}{|c|c|c|c|c|c|c|c|c|c|c|}
\hline & \multicolumn{2}{|c|}{ Output Slacks } & \multicolumn{3}{|c|}{ Input Slacks } & \multicolumn{2}{|c|}{ Output Targets } & \multicolumn{3}{|c|}{ Input Targets } \\
\hline Year & 1 & 2 & 1 & 2 & 3 & 1 & 2 & 1 & 2 & 3 \\
\hline 2005 & 0.000 & 8.604 & 0.000 & 0.000 & 0.000 & 258.762 & 15.537 & 8.610 & 3.250 & 47.720 \\
\hline 2006 & 0.000 & 9.272 & 0.000 & 1.276 & 0.000 & 345.925 & 18.872 & 11.580 & 2.874 & 82.200 \\
\hline 2007 & 0.000 & 9.768 & 0.000 & 1.271 & 0.000 & 379.177 & 21.539 & 11.090 & 3.639 & 130.980 \\
\hline 2008 & 0.000 & 12.362 & 0.000 & 0.000 & 0.000 & 366.840 & 24.374 & 10.000 & 4.460 & 146.100 \\
\hline
\end{tabular}


Table 6: Summary of the bank's DEA-efficiency scores in model-M2.

\begin{tabular}{|c|c|c|c|c|c|c|}
\hline Year & The country & The bank & crste & vrste & Scale & rts \\
\hline 2005 & UK & IBB & 0.326 & 1.000 & 0.326 & irs \\
\hline 2005 & Qatar & Qatar Islamic Bank & 0.969 & 1.000 & 0.969 & irs \\
\hline 2005 & Kuwait & Kuwait Finance House & 0.848 & 0.880 & 0.963 & drs \\
\hline 2005 & Bahrain & Albaraka Islamic bank Group & 0.512 & 0.517 & 0.992 & irs \\
\hline 2005 & K.S.A & Bank Albilad & 0.691 & 0.801 & 0.862 & irs \\
\hline 2005 & K.S.A & Al Rajhi Bank & 1.000 & 1.000 & 1.000 & - \\
\hline 2005 & K.S.A & Aljazira & 0.715 & 0.736 & 0.971 & $\mathrm{drs}$ \\
\hline 2005 & U.A,E & Emirates Islamic Bank & 0.771 & 1.000 & 0.771 & irs \\
\hline 2005 & U.A.E & DIB & 1.000 & 1.000 & 1.000 & - \\
\hline 2005 & Malaysia & Bank Islam(BIMB) & 0.682 & 0.731 & 0.933 & irs \\
\hline 2006 & UK & IBB & 0.321 & 0.658 & 0.488 & irs \\
\hline 2006 & Qatar & Qatar Islamic Bank & 1.000 & 1.000 & 1.000 & - \\
\hline 2006 & Kuwait & Kuwait Finance House & 0.741 & 0.816 & 0.908 & drs \\
\hline 2006 & Bahrain & Albaraka Islamic bank Group & 0.590 & 0.593 & 0.995 & irs \\
\hline 2006 & K.S.A & Bank Albilad & 0.512 & 0.536 & 0.956 & irs \\
\hline 2006 & K.S.A & Al Rajhi Bank & 1.000 & 1.000 & 1.000 & - \\
\hline 2006 & K.S.A & Aljazira & 1.000 & 1.000 & 1.000 & - \\
\hline 2006 & U.A,E & Emirates Islamic Bank & 0.814 & 0.960 & 0.848 & irs \\
\hline 2006 & U.A.E & DIB & 0.882 & 0.914 & 0.966 & drs \\
\hline 2006 & Malaysia & Bank Islam & 0.513 & 0.547 & 0.938 & irs \\
\hline 2007 & UK & IBB & 0.360 & 0.700 & 0.515 & irs \\
\hline 2007 & Qatar & Qatar Islamic Bank & 0.956 & 1.000 & 0.956 & irs \\
\hline 2007 & Kuwait & Kuwait Finance House & 0.969 & 1.000 & 0.969 & drs \\
\hline 2007 & Bahrain & Albaraka Islamic bank Group & 0.641 & 0.648 & 0.989 & drs \\
\hline 2007 & K.S.A & Bank Albilad & 0.469 & 0.480 & 0.978 & irs \\
\hline 2007 & K.S.A & Al Rajhi Bank & 1.000 & 1.000 & 1.000 & - \\
\hline 2007 & K.S.A & Aljazira & 0.448 & 0.487 & 0.920 & drs \\
\hline 2007 & U.A,E & Emirates Islamic Bank & 0.774 & 0.825 & 0.939 & irs \\
\hline 2007 & U.A.E & DIB & 0.831 & 0.854 & 0.973 & drs \\
\hline 2007 & Malaysia & Bank Islam & 0.468 & 0.481 & 0.974 & irs \\
\hline 2008 & UK & IBB & 0.394 & 0.869 & 0.453 & irs \\
\hline 2008 & Qatar & Qatar Islamic Bank & 1.000 & 1.000 & 1.000 & - \\
\hline 2008 & Kuwait & Kuwait Finance House & 0.834 & 1.000 & 0.834 & drs \\
\hline 2008 & Bahrain & Albaraka Islamic bank Group & 0.592 & 0.618 & 0.958 & drs \\
\hline 2008 & K.S.A & Bank Albilad & 0.460 & 0.467 & 0.984 & irs \\
\hline 2008 & K.S.A & Al Rajhi Bank & 0.918 & 1.000 & 0.918 & drs \\
\hline 2008 & K.S.A & Aljazira & 0.400 & 0.403 & 0.994 & irs \\
\hline 2008 & U.A,E & Emirates Islamic Bank & 0.824 & 0.829 & 0.994 & irs \\
\hline 2008 & U.A.E & DIB & 0.665 & 0.667 & 0.996 & $\mathrm{drs}$ \\
\hline \multirow[t]{2}{*}{2008} & Malaysia & Bank Islam & 0.450 & 0.456 & 0.986 & irs \\
\hline & & Mean & 0.709 & 0.787 & 0.905 & \\
\hline
\end{tabular}

$*($ Crste $)=$ Overall (total) efficiency scores, $($ Vrste $)=$ Pure technical efficiency scores $($ Scale) $=$ Scale efficiency, and (rts) $=$ return to scale. ** All banks that have been chosen in the sample of Islamic banks, whether in GCC-States or in Malaysia, are from the top (50) Islamic banks as at 31/12/2007.

*** Geographically speaking, Turkey belongs to Europe. In recent years some sources consider Turkey to be more closely aligned with Europe based on their modern economic and political trends. However, Turkey has become increasingly integrated with the west through membership in organizations such as the Council of Europe, NATO, OECD, OSCE and the G-20 major economies.

Table 6.1: Summary of DEA- slacks and targets (IBB: model-M2).

\begin{tabular}{|l|c|c|c|c|c|c|c|c|c|c|}
\hline & \multicolumn{2}{|c|}{ Output Slacks } & \multicolumn{3}{|c|}{ Input Slacks } & \multicolumn{2}{c|}{ Output Targets } & \multicolumn{3}{c|}{ Input Targets } \\
\hline Year & 1 & 2 & 1 & 2 & 3 & 1 & 2 & 1 & 2 & 3 \\
\hline $\mathbf{2 0 0 5}$ & 0.000 & 0.000 & 0.000 & 0.000 & 0.000 & 82.490 & 2.210 & 8.610 & 3.250 & 47.720 \\
\hline $\mathbf{2 0 0 6}$ & 0.000 & 5.784 & 1.102 & 0.000 & 0.000 & 161.046 & 10.254 & 10.478 & 4.150 & 82.200 \\
\hline $\mathbf{2 0 0 7}$ & 0.000 & 6.664 & 0.000 & 0.000 & 0.000 & 206.557 & 13.076 & 11.090 & 4.910 & 130.980 \\
\hline $\mathbf{2 0 0 8}$ & 0.000 & 3.279 & 0.000 & 0.000 & 7.510 & 169.345 & 8.824 & 10.000 & 4.460 & 138.590 \\
\hline
\end{tabular}


Table 7: Summary of the bank's DEA-efficiency scores in model-M3

\begin{tabular}{|c|c|c|c|c|c|}
\hline Year & The Bank & crste & vrste & scale & rts \\
\hline 2005 & IBB & 1.000 & 1.000 & 1.000 & - \\
\hline 2005 & Turkish Bank (UK) Limited & 893 & 0.916 & 0.975 & irs \\
\hline 2005 & ICBC London Limited & 1.000 & 1.000 & 1.000 & - \\
\hline 2005 & Habib Allied INT. Bank Plc & 0.873 & 0.905 & 0.966 & drs \\
\hline 2005 & Ghana INT. Bnak & 1.000 & 1.000 & 1.000 & - \\
\hline 2005 & Bank of Beirut(UK)Ltd & 0.964 & 1.000 & 0.964 & irs \\
\hline 2005 & Bank Leumi UK & 0.896 & 0.993 & 0.902 & drs \\
\hline 2006 & IBB & 0.825 & 0.901 & 0.916 & drs \\
\hline 2006 & Turkish Bank (UK) Limited & 0.860 & 0.878 & 0.980 & irs \\
\hline 2006 & ICBC London Limited & 0.990 & 1.000 & 0.990 & irs \\
\hline 2006 & Habib Allied INT. Bank Plc & 0.906 & 0.948 & 0.955 & drs \\
\hline 2006 & Ghana INT. Bnak & 1.000 & 1.000 & 1.000 & - \\
\hline 2006 & Bank of Beirut(UK)Ltd & 0.670 & 0.899 & 0.746 & irs \\
\hline 2006 & Bank Leumi UK & 0.949 & 1.000 & 0.949 & drs \\
\hline 2007 & IBB & 0.815 & 0.898 & 0.908 & drs \\
\hline 2007 & Turkish Bank (UK) Limited & 0.860 & 0.860 & 1.000 & - \\
\hline 2007 & ICBC London Limited & 1.000 & 1.000 & 1.000 & - \\
\hline 2007 & Habib Allied INT. Bank Plc & 0.938 & 0.978 & 0.959 & drs \\
\hline 2007 & Ghana INT. Bnak & 1.000 & 1.000 & 1.000 & - \\
\hline 2007 & Bank of Beirut(UK)Ltd & 0.774 & 0.847 & 0.913 & irs \\
\hline 2007 & Bank Leumi UK & 0.964 & 1.000 & 0.964 & drs \\
\hline 2008 & IBB & 0.789 & 0.856 & 0.922 & drs \\
\hline 2008 & Turkish Bank (UK) Limited & 0.947 & 0.997 & 0.949 & irs \\
\hline 2008 & ICBC London Limited & 1.000 & 1.000 & 1.000 & - \\
\hline 2008 & Habib Allied INT. Bank Plc & 0.938 & 0.977 & 0.960 & drs \\
\hline 2008 & Ghana INT. Bnak & 0.884 & 1.000 & 0.884 & drs \\
\hline 2008 & Bank of Beirut(UK)Ltd & 1.000 & 1.000 & 1.000 & - \\
\hline 2008 & Bank Leumi UK & 0.973 & 1.000 & 0.973 & drs \\
\hline
\end{tabular}

Table 7.1: Summary of DEA slacks and targets (IBB: model-M3)

\begin{tabular}{|c|c|c|c|c|c|c|c|c|c|c|}
\hline & \multicolumn{3}{|c|}{ Output Slacks } & \multicolumn{3}{|c|}{ Input Slacks } & \multicolumn{3}{c|}{ Output Targets } & \multicolumn{3}{c|}{ Input Targets } \\
\hline Year & $\mathbf{1}$ & $\mathbf{2}$ & $\mathbf{1}$ & $\mathbf{2}$ & $\mathbf{3}$ & $\mathbf{1}$ & $\mathbf{2}$ & $\mathbf{1}$ & $\mathbf{2}$ & $\mathbf{3}$ \\
\hline $\mathbf{2 0 0 5}$ & 0.000 & 0.000 & 0.000 & 0.000 & 0.000 & 82.490 & 2.210 & 8.610 & 3.25 & 47.7 \\
\hline $\mathbf{2 0 0 6}$ & 0.000 & 0.000 & 2.71 & 0.986 & 0.000 & 117.641 & 3.265 & 8.870 & 3.164 & 82.2 \\
\hline $\mathbf{2 0 0 7}$ & 0.000 & 0.000 & 2.211 & 1.861 & 0.000 & 161.002 & 4.998 & 8.879 & 3.049 & 131 \\
\hline $\mathbf{2 0 0 8}$ & 0.000 & 0.000 & 1.259 & 1.443 & 0.000 & 171.945 & 5.630 & 8.741 & 3.017 & 146 \\
\hline
\end{tabular}


Table 8

Summary of the bank's DEA-efficiency scores in model -M4

\begin{tabular}{|c|c|c|c|c|c|}
\hline Year & The Bank & crste & vrste & scale & rts \\
\hline 2005 & IBB & 0.354 & 1.000 & 0.354 & irs \\
\hline 2005 & The Royal Bank of Scotland plc & 0.476 & 0.946 & 0.503 & drs \\
\hline 2005 & National Westminster Bank Plc & 0.636 & 0.667 & 0.953 & drs \\
\hline 2005 & Lloyds TSB Bank plc & 1.000 & 1.000 & 1.000 & - \\
\hline 2005 & Bank of Scotland plc & 1.000 & 1.000 & 1.000 & - \\
\hline 2005 & HBOS plc & 1.000 & 1.000 & 1.000 & - \\
\hline 2005 & Standard Chartered & 0.445 & 0.517 & 0.861 & drs \\
\hline 2005 & Northern Rock plc & 0.926 & 0.927 & 0.998 & irs \\
\hline 2005 & HSBC bank Plc & 0.436 & 0.705 & 0.618 & $\mathrm{drs}$ \\
\hline 2005 & Abbey National & 0.397 & 0.634 & 0.626 & drs \\
\hline 2005 & Alliance and Leicester & 0.591 & 0.593 & 0.997 & irs \\
\hline 2005 & Barclays PLC & 0.442 & 0.791 & 0.559 & drs \\
\hline 2005 & The Co-operative Bank Plc & 0.467 & 0.474 & 0.984 & irs \\
\hline 2005 & Bradford and Bingley & 0.725 & 0.736 & 0.986 & irs \\
\hline 2006 & IBB & 0.269 & 0.434 & 0.619 & irs \\
\hline 2006 & The Royal Bank of Scotland plc & 0.479 & 0.954 & 0.502 & drs \\
\hline 2006 & National Westminster Bank Plc & 0.625 & 0.937 & 0.667 & drs \\
\hline 2006 & Lloyds TSB Bank plc & 0.907 & 1.000 & 0.907 & drs \\
\hline 2006 & Bank of Scotland plc & 1.000 & 1.000 & 1.000 & - \\
\hline 2006 & HBOS plc & 1.000 & 1.000 & 1.000 & - \\
\hline 2006 & Standard Chartered & 0.443 & 0.511 & 0.868 & drs \\
\hline 2006 & Northern Rock plc & 1.000 & 1.000 & 1.000 & - \\
\hline 2006 & HSBC bank Plc & 0.432 & 0.737 & 0.586 & drs \\
\hline 2006 & Abbey National & 0.456 & 0.699 & 0.652 & drs \\
\hline 2006 & Alliance and Leicester & 0.619 & 0.620 & 0.997 & irs \\
\hline 2006 & Barclays PLC & 0.487 & 0.807 & 0.603 & $\mathrm{drs}$ \\
\hline 2006 & The Co-operative Bank Plc & 0.557 & 0.575 & 0.969 & irs \\
\hline 2006 & Bradford and Bingley & 0.734 & 0.743 & 0.988 & irs \\
\hline 2007 & IBB & 0.254 & 0.413 & 0.616 & irs \\
\hline 2007 & The Royal Bank of Scotland plc & 0.504 & 1.000 & 0.504 & drs \\
\hline 2007 & National Westminster Bank Plc & 0.640 & 1.000 & 0.640 & $\mathrm{drs}$ \\
\hline 2007 & Lloyds TSB Bank plc & 0.802 & 0.965 & 0.831 & drs \\
\hline 2007 & Bank of Scotland plc & 0.982 & 1.000 & 0.982 & drs \\
\hline 2007 & HBOS plc & 0.983 & 1.000 & 0.983 & drs \\
\hline 2007 & Standard Chartered & 0.448 & 0.535 & 0.838 & drs \\
\hline 2007 & Northern Rock plc & 1.000 & 1.000 & 1.000 & - \\
\hline 2007 & HSBC bank Plc & 0.463 & 0.762 & 0.608 & drs \\
\hline 2007 & Abbey National & 0.528 & 0.781 & 0.676 & drs \\
\hline 2007 & Alliance and Leicester & 0.577 & 0.578 & 1.000 & - \\
\hline 2007 & Barclays PLC & 0.467 & 0.855 & 0.547 & drs \\
\hline 2007 & The Co-operative Bank Plc & 0.404 & 0.410 & 0.986 & irs \\
\hline 2007 & Bradford and Bingley & 0.712 & 0.721 & 0.988 & irs \\
\hline 2008 & IBB & 0.255 & 0.624 & 0.409 & irs \\
\hline 2008 & The Royal Bank of Scotland plc & 0.329 & 1.000 & 0.329 & drs \\
\hline 2008 & National Westminster Bank Plc & 0.602 & 1.000 & 0.602 & drs \\
\hline 2008 & Lloyds TSB Bank plc & 0.347 & 0.885 & 0.392 & drs \\
\hline 2008 & Bank of Scotland plc & 0.912 & 1.000 & 0.912 & drs \\
\hline 2008 & HBOS plc & 0.862 & 0.986 & 0.874 & drs \\
\hline 2008 & Standard Chartered & 0.474 & 0.598 & 0.793 & drs \\
\hline 2008 & Northern Rock plc & 0.738 & 0.738 & 1.000 & - \\
\hline 2008 & HSBC bank Plc & 0.523 & 0.809 & 0.647 & drs \\
\hline 2008 & Abbey National & 0.623 & 0.999 & 0.623 & drs \\
\hline 2008 & Alliance and Leicester & 0.339 & 0.502 & 0.675 & drs \\
\hline 2008 & Barclays PLC & 0.458 & 0.964 & 0.475 & drs \\
\hline 2008 & The Co-operative Bank Plc & 0.429 & 0.434 & 0.987 & irs \\
\hline \multirow[t]{2}{*}{2008} & Bradford and Bingley & 0.989 & 1.000 & 0.989 & irs \\
\hline & Mean & 0.617 & 0.796 & 0.780 & \\
\hline
\end{tabular}


Table 8.1: Summary of DEA- slacks and targets (IBB: model-M4)

\begin{tabular}{|c|c|c|c|c|c|c|c|c|c|c|}
\hline & \multicolumn{2}{|c|}{ Output Slacks } & \multicolumn{3}{|c|}{ Input Slacks } & \multicolumn{2}{|c|}{ Output Targets } & \multicolumn{3}{|c|}{ Input Targets } \\
\hline Year & 1 & 2 & 1 & 2 & 3 & 1 & 2 & 1 & 2 & 3 \\
\hline 2005 & 0.000 & 0.000 & 0.000 & 0.000 & 0.000 & 82.490 & 2.210 & 8.610 & 3.250 & 47.720 \\
\hline 2006 & 0.000 & 0.000 & 0.000 & 0.482 & 0.000 & 243.871 & 6.768 & 11.580 & 3.668 & 82.200 \\
\hline 2007 & 0.000 & 0.000 & 0.000 & 0.453 & 0.000 & 350.341 & 10.876 & 11.090 & 4.457 & 130.980 \\
\hline 2008 & 0.000 & 0.000 & 0.000 & 0.478 & 31.931 & 236.056 & 7.730 & 10.000 & 3.982 & 114.169 \\
\hline
\end{tabular}

Table 9: Summary results of the regression analysis

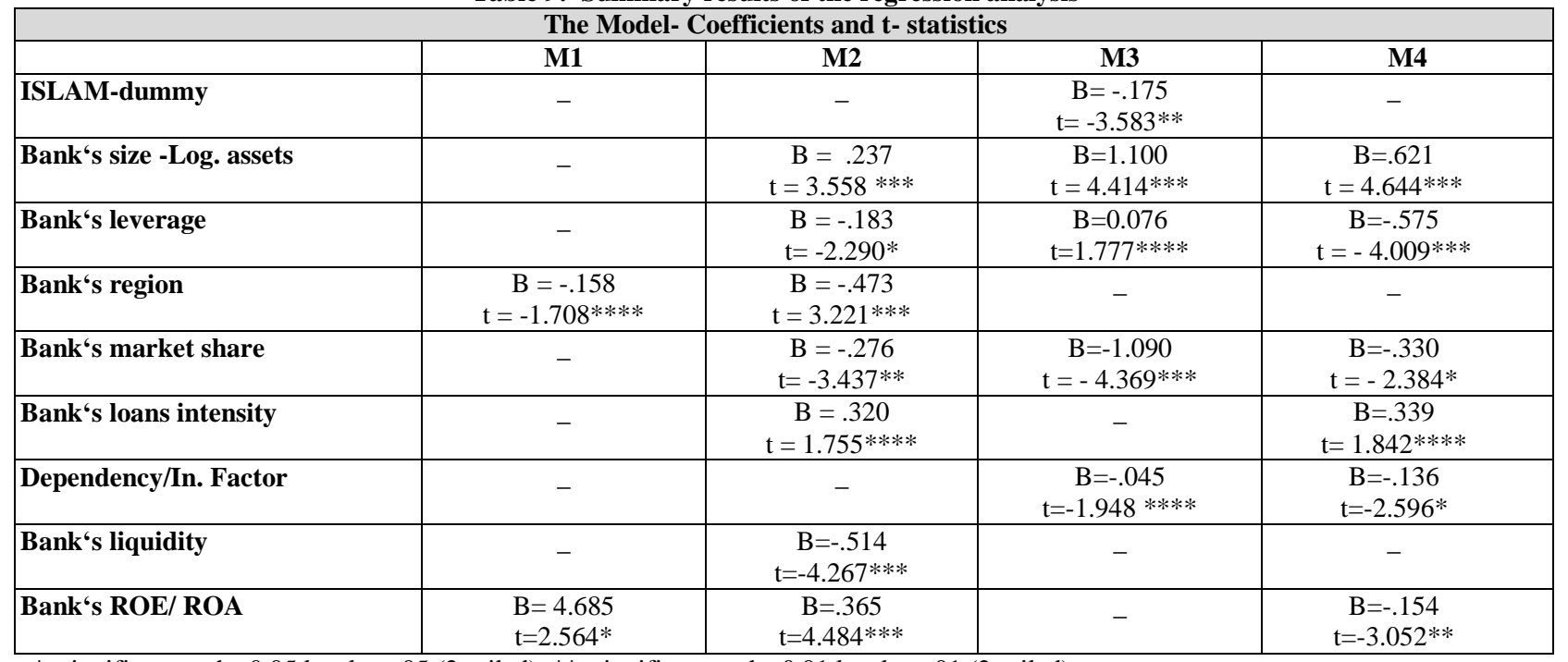

*: significant at the 0.05 level-p<.05 (2-tailed), **: significant at the 0.01 level-p<.01 (2-tailed),

$* * *$ : significant at the 0.001 level (2-tailed) $\mathrm{p}<0.1 \%$, ****: significant at the 0.10 level-p<.10 (2-tailed)

Note: For the sake of parsimony, the table displays only the estimated "Beta" and the " $t$ " values. 
Table 10

Summary statistics of the variables employed in the 4 models of DEA

\begin{tabular}{|c|c|c|c|c|c|}
\hline \multicolumn{6}{|c|}{ All numbers are expressed in million $£$ after deflation. } \\
\hline Outputs-Inputs & $\mathbf{N}$ & Minimum & Maximum & Mean & Std. Deviation \\
\hline \multicolumn{6}{|l|}{ M1 } \\
\hline Total Loans & 48 & 0.440 & $1,567.810$ & 596.770 & 414.086 \\
\hline Total Revenues & 48 & 0.580 & 263.530 & 69.251 & 58.834 \\
\hline Total Expenses & 48 & 3.810 & $16,768.770$ & 388.629 & $2,415.026$ \\
\hline Total Staff Cost & 48 & 0.900 & 698.570 & 24.998 & 99.656 \\
\hline Total Deposits & 48 & 2.700 & $3,172.440$ & 761.526 & 598.330 \\
\hline \multicolumn{6}{|l|}{ M2 } \\
\hline Total Loans & 40 & 82.490 & $22,668.570$ & $4,237.159$ & $5,050.672$ \\
\hline Total Revenues & 40 & 2.210 & 1823.300 & 411.548 & 494.508 \\
\hline Total Expenses & 40 & 8.61 & 1005.16 & 152.464 & 194.139 \\
\hline Total Staff Cost & 40 & 3.250 & 253.120 & 61.228 & 57.989 \\
\hline Total Deposits & 40 & 47.720 & $19,682.360$ & $4,223.458$ & $4,589.773$ \\
\hline \multicolumn{6}{|l|}{ M3 } \\
\hline Total Loans & 28 & 29.400 & $1,278.720$ & 298.965 & 354.175 \\
\hline Total Revenues & 28 & 2.211 & 38.110 & 10.927 & 10.700 \\
\hline Total Expenses & 28 & 1.510 & 19.600 & 7.089 & 5.446 \\
\hline Total Staff Cost & 28 & 0.850 & 10.710 & 3.494 & 2.722 \\
\hline Total Deposits & 28 & 47.720 & $1,214.390$ & 323.312 & 348.269 \\
\hline \multicolumn{6}{|l|}{ M4 } \\
\hline Total Loans & 56 & 105.940 & $644,732.470$ & $20,3774.686$ & 1.730 \\
\hline Total Revenues & 56 & 2.940 & $53,775.550$ & $12,522.143$ & $14,615.558$ \\
\hline Total Expenses & 56 & 10.000 & $39,902.580$ & $7,919.875$ & $10,505.427$ \\
\hline Total Staff Cost & 56 & 4.150 & $8,027.700$ & $2,109.719$ & $2,234.654$ \\
\hline Total Deposits & 56 & 82.200 & $585,895.760$ & $175,343.687$ & 1.571 \\
\hline
\end{tabular}

Table 11

Correlation matrix between inputs and outputs (M1-M4).

\begin{tabular}{|c|c|c|c|c|}
\hline The Model & Revenue & T. Expenses & T. Staff Cost & T Deposits \\
\hline \multicolumn{5}{|l|}{ M1 } \\
\hline T. Loans & 0.767 & 0.631 & 0.524 & 0.799 \\
\hline T. Revenues & 1.000 & 0.813 & 0.726 & 0.753 \\
\hline T. Expenses & & 1.000 & 0.502 & 0.776 \\
\hline T. Staff Cost & & & 1.000 & 0.545 \\
\hline \multicolumn{5}{|l|}{ M2 } \\
\hline T. Loans & 0.896 & 0.928 & 0.934 & 0.854 \\
\hline T. Revenues & 1.000 & 0.890 & 0.900 & 0.798 \\
\hline T. Expenses & & 1.000 & 0.939 & 0.833 \\
\hline T. Staff Cost & & & 1.000 & 0.827 \\
\hline \multicolumn{5}{|l|}{ M3 } \\
\hline T. Loans & 0.799 & 0.638 & 0.651 & 0.845 \\
\hline T. Revenues & 1.000 & 0.546 & 0.587 & 0.971 \\
\hline T. Expenses & & 1.000 & 0.937 & 0.497 \\
\hline T. Staff Cost & & & 1.000 & 0.533 \\
\hline \multicolumn{5}{|l|}{ M4 } \\
\hline T. Loans & 0.920 & 0.937 & 0.874 & 0.959 \\
\hline T. Revenues & 1.000 & 0.966 & 0.839 & 0.881 \\
\hline T. Expenses & & 1.000 & 0.853 & 0.912 \\
\hline T. Staff Cost & & & 1.000 & 0.933 \\
\hline
\end{tabular}

Correlation is significant at the 0.01 level (2-tailed) 
Table 12

Summary of the exogenous variables used in the second -stage of DEA.

\begin{tabular}{|c|c|c|}
\hline Exogenou & s variables & The measurement and the expected effect on efficiency \\
\hline$\beta 1 B P_{j t}$ & $(\mathrm{E} 1, \mathrm{E} 2)$ & Profitability $=$ net income to total assets. $(+)^{*}$ \\
\hline$\beta 2 P e r_{j t}$ & $(\mathrm{E} 1, \mathrm{E} 2)$ & $\begin{array}{l}\text { Personal expenses as a proxy of skills utilization measured by total amount of wages and salaries to } \\
\text { total assets. (-): "efficient banks are expected to have lower cost because of IT". }\end{array}$ \\
\hline$\beta 3 L_{\text {Liq }}$ & $(\mathrm{E} 1, \mathrm{E} 2)$ & Liquid assets to total deposits and short term funding as a proxy of liquid asset ratio. (+ or -) \\
\hline$\beta 4 \log (A)_{j t}$ & $(\mathrm{E} 1, \mathrm{E} 2)$ & The logarithm of total assets as a proxy of size. $(+)$ \\
\hline$\beta 5 L T A_{j t}$ & $(\mathrm{E} 1, \mathrm{E} 2)$ & The proxy of lending intensity= total Loans to total asset. $(+)$ : loans are the main source of revenue. \\
\hline$\beta 6$ Depo $_{j t}$ & $(\mathrm{E} 1, \mathrm{E} 2)^{* *}$ & $\begin{array}{l}\text { Total deposits as a proxy of banks market share. }(+) \text { : deposits are considered the main source of banks } \\
\text { progress. }\end{array}$ \\
\hline$\beta 7$ Ind $_{j t}$ & $(\mathrm{E} 1, \mathrm{E} 2)^{* * *}$ & $\begin{array}{l}\text { The effect of independency. Dummy variable; (1) if a bank is managed by parents (subsidiary), (0) if } \\
\text { it is stand alone bank. (+ or -) }\end{array}$ \\
\hline$\beta 8 A g e_{j t}$ & $(\mathrm{E} 1, \mathrm{E} 2) * * * *$ & The effect of age and experience. Dummy variable; $(1)$ if < 10 years, $(0)$ otherwise. $(+)$ \\
\hline$\beta 9$ Lev $_{j t}$ & $(\mathrm{E} 1, \mathrm{E} 2)^{* * * * *}$ & Financial leverage $=$ total assets to equity. $(-)$ \\
\hline$\beta 10 G D P_{j t}$ & $(\mathrm{E} 1)$ & $\begin{array}{l}\text { The percentage change in gross domestic production per capita (favorable economic condition will } \\
\text { affect positively on demand and supply of banking services). (+ or -) }\end{array}$ \\
\hline$\beta$ 10Diver $_{j \mathrm{t}}$ & (E2) & $\begin{array}{l}\text { Diversification effect. Dummy variable; (1) if high diversified, (0) otherwise. (+): Unless it leads to } \\
\text { higher risk. }\end{array}$ \\
\hline$\beta 11 G e o_{j t}$ & (E1) & $\begin{array}{l}\text { Geographical location effect. Dummy variable; }(1) \text { if the bank is located in Europe; }=(0) \text { otherwise. } \\
(+) \text { : Islamic banks in Muslim countries are more efficient. }\end{array}$ \\
\hline$\beta 12$ Islam $_{j t}$ & $(\mathrm{E} 2)$ & Dummy variable; $(1)$ if an Islamic bank; $=(0)$ otherwise. $(+$ or -$)$ \\
\hline
\end{tabular}

$*(+)$ indicates a positive effect, (-) indicates a negative (inverse) effect, while (0) indicates (No) effect.

** The market share of a bank is measured by dividing the amount of its deposits by the total amount of all sample bank's deposits in a local market. The sample banks represent the majority of major banks deposits in a banking industry.

*** The term dependency means: a) Islamic banks managed by conventional banks. b) Banks operate as subsidiary or a member (part) of a banking group. Independent banks are "stand alone banks".

**** In this paper, we introduced (5) dummies to avoid the dummy trap in order to get away from the perfect multi co-linearity. However, the number of dummy variables is not important, what matter is whether the sum of any of the dummies is the same for all observations.

****** A core issue in the corporate governance is the nature of the relationship between the level of debt in the bank's capital structure and economic performance. Thus, we can measure the relationship between the DEA scores and leverage as a proxy of corporate governance as well. 
Table 13: Overall results from testing the "OLS" main assumptions.

\begin{tabular}{|c|c|c|}
\hline The Assumption & The Test & The Results Of Our Analysis \\
\hline \multirow{3}{*}{ i. $\quad$ Non-Multicolinearity } & - Tolerance & $\mathrm{T}>0.20$ \\
\hline & - Variance -Inflation Factor & $\mathrm{VIF} \leq 4$ \\
\hline & - Durbin-Watson & $\mathrm{D}-\mathrm{W} \approx 2\left(\mathrm{P}>0.05^{*}\right)$ \\
\hline ii. $\quad$ Normality** & Skewness & Skew is within the range $(+1$ to -1$)$ \\
\hline iii. $\quad$ Linearity & Scatter-Plots & Certainly been met \\
\hline
\end{tabular}

Model results:

1. $\mathrm{R}^{2}>56 \%(\mathrm{M} 1=56.7 \%$; $2=67.5 \%$; $\mathrm{M} 3=73.9 \%$; and $\mathrm{M} 4=62.8 \%)$, this illustrate a strong correlation between the observed value of the response variable and the values predicted by the model.

2. ANOVA*** $_{* *} \mathrm{M} 1, \mathrm{~F}_{12,35}=3.825, P<.01 ; \mathrm{M} 2, \mathrm{~F}_{11,28}=5.297, P<.001 ; \mathrm{M} 3, \mathrm{~F}_{11},{ }_{16}=4.128, P<.001 ; \mathrm{M} 4, \mathrm{~F}_{10,45}=7.608, P<.001$

* The $p$-value tests for serial correlation. Since the $p$-value is greater than 0.05 , then there is no serial correlation and the data are fine.

** Despite the fact that the multiple regression procedures are not greatly affect by minor deviations from the assumptions of linearity and normality of data, and to produce more accurate results, we use the nonlinear transformation to meet the foregoing assumptions.

***we clearly reject the null hypothesis and conclude that at least one of the predictors is related to the efficiency scores. This means that the models that have been estimated are theoretically construct and statistically significant.

Additional notes:

I. In order to get rid the negative values for a variable, we add a constant to move the minimum value of the distribution above 0 . Hence, we use $\log +4$ in our analysis to transfer the logarithms results to a positive numbers. Furthermore, for the original data values include negative number, it is not possible to apply many nonlinear transformations, in this situation we add a constant to all data values that make them positive, as a rule of thumb, we add the smallest constant that will convert the largest negative data value to a value greater than 1 .

II. It is worth noting that the DEA model requires the input and output data to be non-negative and preferably strictly positive (no zero value), therefore, it is necessary to transfer the negative data into positive one. One of the more common methods for eliminating this problem has been through the addition of a sufficiently large positive constant to the values of the input or output that has the negative number (Ali and Seiford, 1990).

III. Formally, DEA is a methodology directed to frontiers rather than central tendencies. In contrast to regression methods, DEA focuses on individual observations and optimizes the performance measure of each unit. A prior knowledge of weights or prices for inputs and outputs is not required in DEA.

Table 14

Summary statistics of the (Mean) values of the independent variables used in the OLS-regression analysis (2005-08)

\begin{tabular}{|l|c|c|c|c|c|c|c|}
\hline Individual/Group banks & ROE & ROA & $\begin{array}{c}\text { Personal } \\
\text { Expenses }\end{array}$ & Liquidity & $\begin{array}{c}\text { Lending } \\
\text { Intensity }\end{array}$ & $\begin{array}{c}\text { Capital } \\
\text { Adequacy }\end{array}$ & Leverage \\
\hline IBB (UK) & 0.257 & 0.055 & 0.406 & 1.263 & 0.911 & 0.245 & 5.527 \\
\hline Islamic Banks in Malaysia & 0.057 & 0.004 & 0.219 & 0.687 & 0.403 & 0.157 & 13.187 \\
\hline Islamic Banks in Turkey & 0.179 & 0.020 & 0.170 & 0.534 & 0.730 & 0.110 & 9.294 \\
\hline Islamic Banks in (GCC) Countries & 0.258 & 0.048 & 0.476 & 2.842 & 0.683 & 0.225 & 5.790 \\
\hline MEAN: Islamic Banks* & 0.165 & 0.024 & 0.289 & 1.354 & 0.605 & 0.164 & 9.424 \\
\hline MEAN: Small Islamic Banks * & 0.149 & 0.029 & 0.347 & 0.988 & 0.614 & 0.237 & 6.814 \\
\hline MEAN: Large Islamic Banks & 0.323 & 0.054 & 0.481 & 0.721 & 0.685 & 0.162 & 7.783 \\
\hline Conventional Banks: UK & 0.446 & 0.090 & 0.459 & 0.762 & 0.685 & 0.109 & 24.365 \\
\hline MEAN: Small Conventional Banks & 0.889 & 0.178 & 0.540 & 0.949 & 0.714 & 0.186 & 7.877 \\
\hline MEAN: Large Conventional Banks & 0.002 & 0.002 & 0.377 & 0.575 & 0.655 & 0.031 & $40.854 * *$ \\
\hline
\end{tabular}

* Only from Muslim countries. **this amount means the bank has $£ 40.854$ of assets for every $£ 1$ of common equity. With leverage of 40.854 , if the value of those assets were to fall, then common stockholders are wiped out. This means the need of more (£) in tangible common equity to absorb losses stemming from what is essentially an over-leveraged financial system. 
Chart 1

Mean efficiency scores by bank- Model "M1"

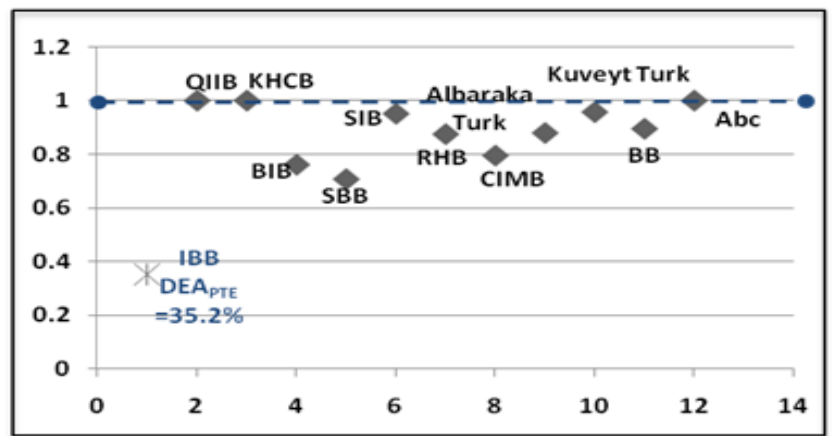

Chart 3

Mean efficiency scores by bank- Model "M3"

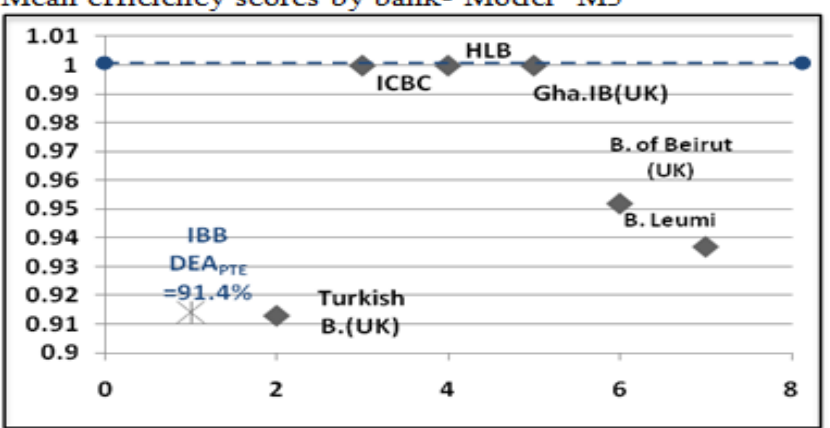

Chart 2

Mean efficiency scores by bank- Model "M2"

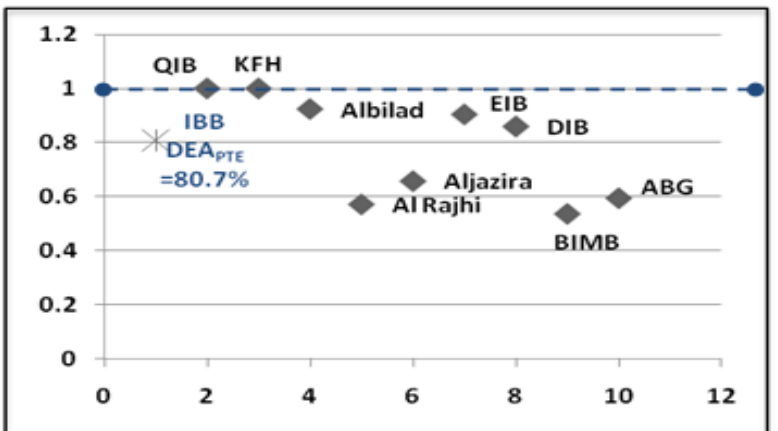

\section{Chart 4}

Mean efficiency scores by bank- Model "M4"

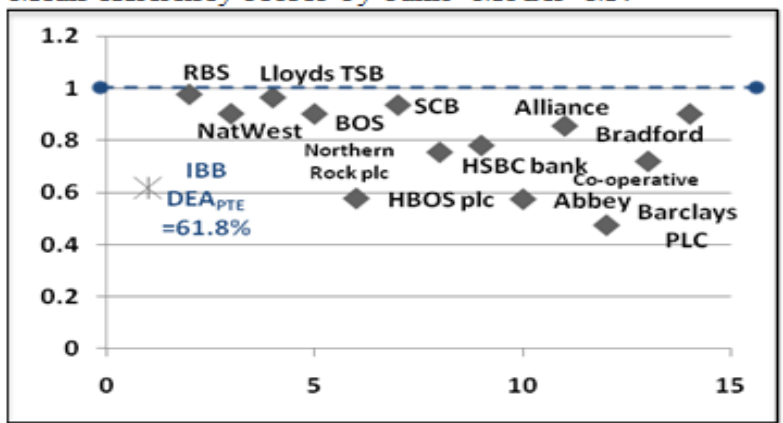

Chart 5

Mean "DEAPTE" scores by group banks within the sample period*

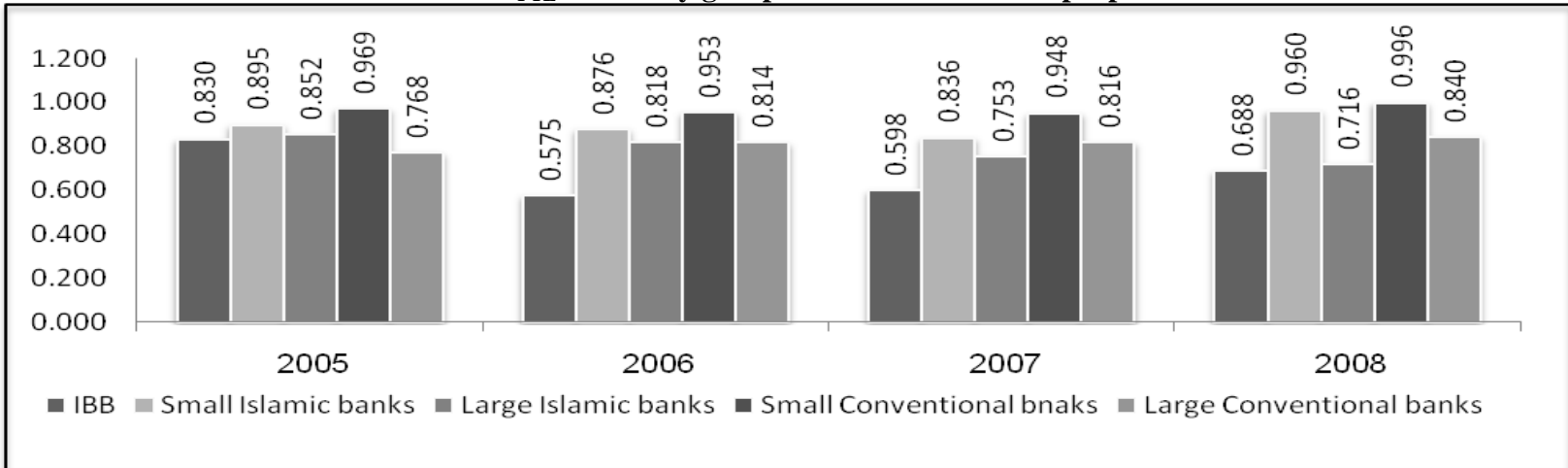

* For IBB, the $\left(\mathrm{DEA}_{\mathrm{PTE}}:{ }_{2005}\right)=(0.319+1+1+1) / 4=0.830$

\section{AUTHOR INFORMATION}

Ahmad M. Abu-Alkheil holds a B.A. degree in Business Administration and an MBA degree in Finance from the University of Jordan. He is currently pursuing his doctoral degree (Dr.Oec: Economics and Business Administration Sciences) at the University of Hohenheim in the field of Banking \& Financial Studies. Mr. Abu-Alkheil's doctoral thesis principally explores his primary research specialty and professional work in Islamic Banking \& Finance. E-mail: alkheil@uni-hohenheim.de. 
Hans-Peter Burghof is professor at the University of Hohenheim and holds the chair of Banking and Finance at the said university. He has extensively worked and published in the areas of credit financing, risk management, and banking systems. Prof. Burghof has made a significant contribution to the development of Stuttgart as an international financial center under the initiative Stuttgart Financial. He serves as a Member of the Council of Stuttgart Stock Exchange. Furthermore, he is director of the Stiftung Kreditwirtschaft and the Hohenheim Management School and member of Supervisory Board at GFT Technologies AG. During the financial crisis, his advice and comments are in great demand by the media and many public and private institutions. E-mail: burghof@uni-hohenheim.de

Walayet A. Khan is a professor of finance at the University of Evansville. He is an active research scholar and maintains a consistent record of scholarly work. He has published papers in numerous finance journals, including the Journal of Financial Research and the Financial Review, Quarterly Journal of Finance and Accounting, Journal of Business and Economics, Applied Business Research, Journal of Economics and Finance, and Journal of Asia Business Studies. Prof. Khan has served as consultant to many national and regional organizations, including the Philadelphia Stock Exchange, the Chicago Stock Exchange, Attain (an electronic communications network), and Kaplan Schweser, Inc. E-mail: wk3@evansville.edu. Corresponding author.

\section{REFERENCES}

1. Ali A.I., \& Seiford L.M. (1990). Translation Invariance in Data Envelopment Analysis. Operations Research Letters, 9 (5), 403-405.

2. Alirezaee, M., Howland, M., \& vandePanne, C. (1998). Sampling size and efficiency bias in data envelopment analysis. Journal of Applied Mathematics \& Decision Sciences, 2 (1), 51-64.

3. Banker, R.D., Charnes, A., \& Cooper, W.W. (1984). Some Models for Estimating Technical and Scale Inefficiencies in Data Envelopment Analysis. Management Science, 30(9), 1078-92.

4. Bauer, P., Berger, A., Ferrier, G., \& Humphrey, D. (1998). Consistency Conditions for Regulatory Analysis of Financial Institutions: A Comparison of Frontier Efficiency Methods. Journal of Economics and Business, 50 (2), 85-114.

5. Berger, A. N., Hancock, D., \& Humphrey, D. B. (1993). Banking efficiency derived from the profit function. Journal of Banking and Finance, 17 (2-3), 317-347.

6. Berger, A.N., \& Humphrey, D.B. (1997). Efficiency of Financial Institutions: International Survey and Directions for Future Research. European Journal of Operational Research, 98 (2), 175-212.

7. Casu, B., \& Molyneux, P. (2003). A Comparative Study of Efficiency in European Banking. Applied Economics, 35 (17), 1865-1876.

8. Charles W. Cobb \& Paul H. Douglas. (1928). A Theory of Production. American Economic Review, 18 (1), 139-165.

9. Charnes, A., Cooper, W.W., \& Rhodes, E. (1978). Measuring the efficiency of decision making units. European Journal of Operational Research, 2 (6), 429-444.

10. Čihák, M., Hesse, H. (2008). Islamic Banks and Financial Stability: An Empirical Analysis. International Monetary Fund, working paper no. 08/16. Retrieved from: http://www.imf.org/external/pubs/ft/wp/2008/wp0816.pdf

11. Coelli T.J. (1996). A guide to DEAP Version 2.1: A Data Envelopment Analysis (Computer) Program. Centre for Efficiency and Productivity Analysis (CEPA), working paper no. 96/08. Retrieved from: http://www.owlnet.rice.edu/ econ380/DEAP.PDF

12. Coelli, T.J., Prasada Rao, D.S., O'Donnell, C.J., \& Battese, G.E. (2005). An Introduction to Efficiency and Productivity Analysis. New York: Springer Science \& Business Media.

13. Cooper, W. W., Seiford, L. M., \& Tone, K. (2006). Introduction to Data Envelopment Analysis and its uses, with DEA-Solver software and references. New York: Springer.

14. Cooper, W. W., Seiford, L. M., \& Tone, K. (2007). Data Envelopment Analysis: A comprehensive Text with Models, Applications, References and DEA-Solver Software. New York: Springer.

15. Cubbins, J., \& Tzanikadis, G. (1998). Regression versus Data Envelopment Analysis for efficiency measurement: An application to the England and Wales regulated water industry. Utilities Policy, 7 (2), 75 85. 
16. Darrat, F., Topuz, C., \& Yousef, T. (2002). Assessing Cost and Technical Efficiency of Banks in Kuwait. Presentation to the Economic Research Forum's 8th Annual Conference in Cairo (January). Retrieved from: http://www.erf.org.eg/CMS/uploads/pdf/1194082688_Assessingcost-Darrat\&Yousef.pdf

17. Farrell, M.J. (1957). The Measurement of Productive Efficiency. Journal of the Royal Statistical Society, 120 (3), 253-290.

18. Gorton, G., \& Winton, A. (1998). Banking in transition economies: Does Efficiency Require Instability? Journal of Money, Credit and Banking, 30 (3), 621-650.

19. Hassoune, A. (2001). Islamic Banks Profitability in an Interest rate cycle. International Journal of Islamic Financial Services, 4 (2).

20. Iqbal, M., \& Molyneux, P. (2005). Thirty Years of Islamic Banking: History, Performance and Prospects. New York: Palgrave Macmillan.

21. Isik, I., \& Hassan, M.K. (2002). Technical, Scale and Allocative Efficiencies of Turkish Banking Industry. Journal of Banking and Finance, 26 (4), 719-766.

22. Jensen, M., \& Meckling, W. (1976). Theory of the Firm: Managerial Behavior, Agency Costs and Ownership Structure. Journal of Financial Economics, 3 (4), 305-360.

23. Jensen, M.C. (1986). Agency costs of free cash flow, corporate finance, and takeovers. American Economic Review, 76 (2), 323-329.

24. Jobst, A. (2007). The Economics of Islamic Finance and Securitization. International Monetary Fund. Working Paper No. 07/117. Retrieved from: http://www.imf.org/external/pubs/ft/wp/2007/wp07117.pdf

25. Kamaruddin, H., Safa, S., \& Mohd, R. (2008). Assessing production efficiency of Islamic banks and conventional banks Islamic windows in Malaysia. MPRA paper no. 10670. Retrieved from: http://mpra.ub.uni-muenchen.de/10670/1/Badrul_31-48.pdf

26. Kapelko, M., Prior-Jimènez, D., \& Rialp-Criado, J. (2008). Intangible assets and efficiency. International analysis in the textile and apparel industry. Ph.D. Dissertation, Universitat Autònoma de Barcelona, Spain. Retrieved from: http://tdx.cat/bitstream/handle/10803/3972/mmk1de1.pdf?sequence=1

27. Kumbhakar, S.C., \& Lovell, C.K. (2000). Stochastic Frontier Analysis. Cambridge: Cambridge University Press.

28. Laeven, Luc, \& Levine, Ross. (2007). Is there a diversification discount in financial conglomerates? Journal of Financial Economics, Elsevier. 85 (2), 331-367.

29. Limam, I. (2001). Measuring Technical Efficiency of Kuwait Banks. Arab Planning Institute - Kuwait, Information Center. Working Paper Series 0101. Retrieved from: http://www.arabapi.org/wps/wps0101.htm

30. McDonald, J. (2009). Using least squares and tobit in second stage DEA efficiency analyses. European Journal of Operational Research, 197 (2), 792-798.

31. Metwally, M.M. (1997). Differences between the Financial Characteristics of Interest- Free Banks and Conventional banks. European Business Review, 97 (2), 92-98.

32. Miller, S., \& Noulas, A. (1996). The Technical Efficiency of Large Banks Production. Journal of Banking and Finance, 20 (3), 495-509.

33. Pedraja-Chaparro, F., Salinas-Jimenez, J., \& Smith, P. (1999). On the quality of data envelopment analysis. Journal of Operational Research Society, 50 (6), 636-44

34. Lønborg, R. (2005). Regulation, Organization and Efficiency: Benchmarking of Publicly and Privately Owned Utility Companies. The 3rd ECPR Conference, Budapest 8th-10th of Sep. Retrieved from: http://regulation.upf.edu/ecpr-05-papers/rlonborg.pdf

35. Rosly, S.A., \& Abu Bakar, M.A. (2003). Performance of Islamic and Mainstream Banks in Malaysia. International Journal of Social Economics, 30 (12), 1249-1265.

36. Samad, A. (2004). Performance of Interest-Free Islamic Banks vis-a-vis Interest-Based Conventional Banks of Bahrain. IIUM Journal of Economics and Management, 12 (2), 1-15

37. Samad, A., \& Hassan, K. (1999). The Performance of Malaysian Islamic Bank during 1984-1997: An Exploratory Study. International Journal of Islamic Financial Services, 1 (3).

38. Sole, J. (2007). Introducing Islamic Banks into Conventional Banking Systems. IMF Working Paper No. 07/175. Retrieved from: http://www.imf.org/external/pubs/ft/wp/2007/wp07175.pdf

39. Sufian, F. (2007). The efficiency of Islamic banking industry: A non-parametric analysis with nondiscretionary input variable. Islamic Economic Studies, 14 (1 \& 2), 53-78. 
40. Sufian, F., A., Majid A., M., \& Zulkhibri (2008). Bank Ownership, Characteristics, and Performance: A Comparative Analysis of Domestic and Foreign Islamic Banks in Malaysia. J.KAU: Islamic Econ., 21 (2), 3-37

41. Sundararajan, V., \& Errico, L. (2002). Islamic Financial Institutions and Products in the Global Financial System: Key Issues in Risk Management and Challenges Ahead. IMF Working Paper No. 02/192. Washington.

42. Yang, Z. (2009). Bank Branch Operating Efficiency: A DEA Approach. Proceedings IMECS. Vol. II. Retrieved from: http://www.iaeng.org/publication/IMECS2009/IMECS2009_pp2087-2092.pdf

43. Yudistira, D. (2004). Efficiency of Islamic Banks: an Empirical Analysis of 18 Banks. Islamic Economic Studies, 12 (1), 1-19 
NOTES 